\title{
R\&D Tax Incentives: Growth Panacea or Budget Trojan Horse?
}

\section{Citation}

Stephen E. Shay, J. Clifton Fleming \& Robert J. Peroni, R\&D Tax Incentives: Growth Panacea or Budget Trojan Horse?, 69 Tax L. Rev. 419 (2016).

\section{Permanent link}

http://nrs.harvard.edu/urn-3:HUL.InstRepos:29012335

\section{Terms of Use}

This article was downloaded from Harvard University's DASH repository, and is made available under the terms and conditions applicable to Other Posted Material, as set forth at http:// nrs.harvard.edu/urn-3:HUL.InstRepos:dash.current.terms-of-use\#LAA

\section{Share Your Story}

The Harvard community has made this article openly available.

Please share how this access benefits you. Submit a story.

\section{Accessibility}




\title{
R\&D Tax Incentives: Growth Panacea or Budget Trojan Horse?
}

\author{
STEPHEN E. SHAY* \\ J. CLIFTON FLEMING, JR.** \\ ROBERT J. PERONI***
}

\section{INTRODUCTION}

Research and development (R\&D) activity has long held a privileged place in the U.S. income tax system and in economic and tax policy debates. This is based on three widely accepted understandings from the economic literature: (1) Technological progress and innovation are important factors in long-term economic growth; (2) knowledge from research activity is foundational in leading to technological progress and innovation; and (3) the "nonrival" nature of knowledge derived from research leads to a risk of "market failure" in which the private returns to investment in $\mathrm{R} \& \mathrm{D}$ will be less than the "social" or public welfare returns from those investments. ${ }^{1}$ The United States re-

* Senior Lecturer on Law, Harvard Law School. I disclose certain activities not connected with my position at Harvard Law School, one or more of which may relate to the subject matter of this Article, at https:/helios.law.harvard.edu/public/ConflictOf InterestReport.aspx?id=10794.

** Ernest L. Wilkinson Chair and Professor of Law, J. Reuben Clark Law School, Brigham Young University.

*** Fondren Foundation Centennial Chair for Faculty Excellence and Professor of Law, The University of Texas School of Law. I thank the University of Texas School of Law for its substantial summer research support.

For helpful comments on earlier drafts of this Article, we thank Lily Batchelder, John Brooks, Brian Galle, Itai Grinberg, David Hasen, Mitchell Kane, Ann Lipton, Leigh Osofsky, Shu-Yi Oei, Darien Shanske, Steven Sheffrin, and participants in the 2015 NYU/ UCLA Tax Policy Symposium on Tax and Entrepreneurship, the Georgetown Tax Law and Public Finance Workshop, and the 2016 Tulane Tax Roundtable. The views expressed in this Article are those of the authors and do not reflect those of their universities, any organization for which any of the authors serves as an officer or renders pro bono services, or, in the case of Stephen Shay, any client.

1 See, e.g., Cong. Budget Office, Federal Support for Research and Development 1 (2007), https://www.cbo.gov/sites/default/files/110th-congress-2007-2008/reports/06-18-research.pdf; Staff of Joint Comm. on Tax'n, 114th Cong., JCX-47-15, Economic Growth and Tax Policy 18 (Comm.Print 2015), https://www.jct.gov/publications.html?func=startdown\& id=4736; Staff of Int'l Monetary Fund, Fiscal Monitor: Acting Now, Acting Together 29, 34 (Apr. 2016), http://www.imf.org/external/pubs/ft/fm/2016/01/pdf/fm1601.pdf ("Innovation is a key driver of long-term productivity growth." . . . Private R\&D undertaken by one firm 
sponds to these understandings with an array of legal, expenditure, and tax law policies that are intended to promote R\&D and innovation activity. ${ }^{2}$ The tax law responses are a number of tax expenditures that have substantial revenue costs and raise serious policy issues. ${ }^{3}$

The political popularity of supporting R\&D tax incentives within the Washington, D.C. "Beltway" is the tax equivalent of embracing motherhood and apple pie. Although there have been proposals for across-the-board cutbacks of tax expenditures, ${ }^{4} \mathrm{R} \& \mathrm{D}$ incentives are unlikely to receive the same treatment. Indeed, legislation adopted at the end of 2015 made the R\&D tax credit permanent at a substantial net revenue cost (that is, the change was not offset by revenue increases or expenditure reductions). ${ }^{5}$ Notwithstanding politicians' talk

may increase productivity in other firms through knowledge spillovers. . . These positive externalities imply that market forces will lead to an under-investment in R\&D compared with the level that is socially efficient." (footnotes omitted)); Asa Hansson \& Cecile Brokelind, Tax Incentives, Tax Expenditures Theories in R\&D: The Case of Sweden, 6 World Tax J. 168, 175-76 (2014). But see Michael D. Rashkin, The Dysfunctional Research Credit Hampers Innovation, 131 Tax Notes 1057, 1059-60 (June 6, 2011) (criticizing the argument that private returns do not capture the full benefit of $R \& D$ expenditures).

2 See Staff of Joint Comm. on Tax'n, 112th Cong., JCX-61-12, Background and Present Law Relating to Manufacturing Activities Within the United States 110 (Comm. Print 2012), https://www.jct.gov/publications.html?func=startdown\&id=4473.

3 See the selected tax expenditure estimates in the Appendix. For a comprehensive introduction to the tax expenditure concept and references to the tax expenditure literature, see J. Clifton Fleming, Jr. \& Robert J. Peroni, Reinvigorating Tax Expenditure Analysis and Its International Dimensions, 27 Va. Tax Rev. 437, 439-45 (2008). For the development of the concept originally, see Stanley S. Surrey \& Paul R. McDaniel, Tax Expenditures 3 (1985); Stanley S. Surrey \& Paul R. McDaniel, The Tax Expenditure Concept and the Budget Reform Act of 1974, 17 B.C. Indus. \& Com. L. Rev. 679, 679-81 (1976). This Article does not engage with the longstanding academic debate regarding the principled or unprincipled nature of tax expenditure analysis. Application of tax expenditure analysis is, for policymaking purposes, a fait accompli. The Congressional Budget and Impoundment Control Act of 1974, $\S \S 3(3), 308,2$ U.S.C. $\S \S 622(3), 639$ (b) (as amended through 2015), defines the term "tax expenditure" and mandates the preparation of an annual tax expenditure budget. Policymakers regularly consult the congressionally mandated tax expenditure budget prepared by Treasury and the tax expenditure analysis prepared by the Staff of the Joint Committee on Taxation.

4 See, e.g., Martin Feldstein, Daniel Feenberg \& Maya MacGuineas, Capping Individual Tax Expenditure Benefits, 131 Tax Notes 505 (May 2, 2011); The Moment of Truth: Report of the National Commission on Fiscal Responsibility and Reform (2010) http://www.fiscal commission.gov/news/moment-truth-report-national-commission-fiscal-responsibility-andreform.

5 Protecting Americans from Tax Hikes Act of 2015, Pub. L. No. 114-113, § 121, 129 Stat. 2242, 3049-52. The change was estimated to cost $\$ 113$ billion over the ten-year budget period from 2016 to 2025. Staff of Joint Comm. on Tax'n, JCX-143-15, Estimated Budget Effects of Division Q of Amendment \#2 to the Senate Amendment to H.R. 2029 (Rules Committee Print 114-40), The "Protecting Americans From Tax Hikes Act of 2015," at 2 (2015), https://www.jct.gov/publications.html?func=startdown\&id=4860. 
of the need for "fundamental" tax reform, ${ }^{6}$ the current tax incentives for $\mathrm{R} \& \mathrm{D}$ have not been subjected to extensive critical examination. ${ }^{7}$

The premises for R\&D tax incentives are grounded in a theoretical analysis in which a key variable, new knowledge that leads to innovation and economic growth- "innovative knowledge"-is not well specified or subjected to rigorous scrutiny. Consequently, the definition and scope of the market failure intended to be targeted by tax incentives is poorly defined. Moreover, our understanding of the process of innovation and economic growth and its linkage to innovative knowledge has been evolving. ${ }^{8}$ Factors contributing to innovation are now understood to include, in addition to innovative knowledge, firmspecific human capital, organizational processes, and knowledge worker and industrial clustering. ${ }^{9}$ These factors affect the ability to achieve welfare spillovers through diffusion of innovative knowledge.

6 White House \& U.S. Treasury Dep't, The President's Framework for Business Tax Reform: An Update 4 (2016), https://www.treasury.gov/resource-center/tax-policy/Documents/The-Presidents-Framework-for-Business-Tax-Reform-An-Update-04-04-2016.pdf ("The Framework would expand incentives for research and development and clean energy while also refocusing the manufacturing deduction.").

7 For a sampling of the relevant literature, see Lily Kahng, The Taxation of Intellectual Capital, 66 Fla. L. Rev. 2229, 2267-77 (2014) (proposing reforms of taxation of intellectual capital, including capitalization of costs); Xuan-Thao Nguyen \& Jeffrey A. Maine, Equity and Efficiency in Intellectual Property Taxation, 76 Brook. L. Rev. 1, 1-8 (2010) (critically assessing equity and efficiency of tax rules for patents, copyrights, and trademarks). Kahng references an extensive literature on the taxation of intangibles, which is an adjacent but distinct subject from the tax treatment of R\&D expenditures. Kahng, supra, at 2232 n.14.

8 See Jason Dedrick \& Kenneth L. Kraemer, Who Captures Value from Science-Based Innovation? The Distribution of Benefits from GMR in the Hard Disk Industry, 44 Res. Pol'y 1615, 1615 (2015) (noting that "questions remain about the relationship of R\&D to economic performance," including the level of contribution and causality); OECD, Supporting Investment in Knowledge Capital, Growth and Innovation 17 (2013), http:// www.oecd-ilibrary.org/docserver/download/9213021e.pdf ("Today's firms are looking beyond research and development $(\mathrm{R} \& \mathrm{D})$ to drive innovation. They invest in a wider range of intangible assets, such as data, software, patents, designs, new organisational processes and firm-specific skills. Together these non-physical assets make up knowledge-based capital."); Alessandro Modica \& Thomas Neubig, Taxation of Knowledge-Based Capital: NonR\&D Investments, Average Effective Tax Rates, Internal vs. External KBC Development and Tax Limitations 7-11 (OECD, Taxation Working Paper No. 24, 2016), http://www.oecdilibrary.org/docserver/download/5jm2f6sfz244.pdf (discussing non-R\&D knowledge-based capital and rationales for related tax incentives, and observing that R\&D capital itself accounts for only $30 \%$ of knowledge-based capital). For a narrative description of the development and commercialization of the internet, which is an example of the process by which a foundational technology developed and became a critical part of the landscape of markets, see Shane Greenstein, How the Internet Became Commercial: Innovation, Privatization, and the Birth of a New Network (2015). This book traces the history of how the internet transitioned from a new technology to an important tool for research institutions to a commercial network to the backbone of digital communication. It also illustrates the varied nature of the contributions of public and private institutions and incentives for development by individuals and commercial and non-commercial participants.

9 See, e.g., OECD, note 8, at 7-9; Int'l Monetary Fund, note 1, at 30 ("[I]nnovation. . . is a broader process that refers not only to the creation of new and improved products and 
The mistargeting problem is not limited to tax instruments. The principal nontax legal incentives to promote innovative knowledge, patents, copyrights, and trade secrets, ${ }^{10}$ are the subject of an ongoing debate as to whether they advance or frustrate innovation. ${ }^{11}$

This Article calls for a re-examination of U.S. R\&D tax incentives under a framework that critically examines the scope of tax incentives and how they fit into an overall U.S. R\&D and innovation incentive regime that marshals government resources to support economic growth. ${ }^{12}$ The framework's objective is to (1) determine whether an $\mathrm{R} \& \mathrm{D}$ tax provision accurately measures income or should be considered a tax incentive/tax expenditure, (2) evaluate whether and the extent to which the tax incentive is necessary to address an identified market failure or other nontax objective, (3) determine whether regulatory or direct expenditure alternatives would be more effective to accomplish the same objective, and (4) if a tax incentive turns out to be the preferred approach, evaluate design alternatives to make the R\&D tax incentive more cost effective.

We examine certain tax incentive provisions that relate to businesses' R\&D activity: the expensing of certain costs, ${ }^{13}$ the allocation of $\mathrm{R} \& \mathrm{D}$ deductions to foreign income, ${ }^{14}$ and the $\mathrm{R} \& \mathrm{D}$ tax credit. ${ }^{15}$ In

processes, but also to organizational change, improved marketing concepts, and new business models (such as e-commerce or the sharing economy).").

10 See U.S. Const. art. I, $\S 8$, cl. 8; 35 U.S.C. $\$ \S 1-390$ (2012) (patent laws); 17 U.S.C. $\S \S 101-1332$ (2012) (copyright laws); 18 U.S.C. $\$ \S 1831-1839$ (2012) (criminal laws relating to the protection of trade secrets).

11 See, e.g., Joseph E. Stiglitz, Intellectual Property Rights, the Pool of Knowledge, and Innovation 1 (Nat'l Bureau of Econ. Research, Working Paper No. 20014, 2014), http:// www.nber.org/papers/w20014.pdf (stating that "[t]he strength and design of IPR [intellectual property rights] affects the extent to which any innovation adds to or subtracts from the pool of ideas that are available to be commercially exploited," and that "stronger intellectual property rights may lead to a lower pace of innovation").

12 See, e.g., Hansson \& Brokelind, note 1, at 73 (analysis of eighteen European countries shows that "R\&D incentives have no statistically significant impact on economic growth").

13 IRC $\S 174$.

14 Reg. $\$ 1.861-17$.

15 IRC $\S 41$. The credit is named the "research and experimentation" credit to track the same term used in $\S 174$. We use the more colloquial term "research and development." In addition to being easier to understand, it avoids the misleading suggestion that eligible expenditures must involve risky experimentation. To prevent a double tax benefit from the same expenditures, $\S 280 \mathrm{C}$ (c) generally prohibits $\S 174$ deductions for expenses claimed as credits under $\S 41(\mathrm{a})$. Under $\S 280 \mathrm{C}$ (c)(3), however, a taxpayer claiming a deduction may elect to also claim a reduced credit. The otherwise allowable credit must be reduced by a percentage equal to the highest corporate tax rate.

This Article does not examine a range of other tax provisions that directly or indirectly relate to R\&D or IP, including $\S 167(f)(1)$ (depreciation of computer software), $\S 167(\mathrm{~g})(8)$ (amortization of expenses incurred in connection with certain musical works and copyrights), § 1221(a)(3) (including in the definition of "capital asset" copyrights, literary, musical, or artistic compositions, letters or memoranda, and similar property), $\S 1221$ (b)(3) (special rules relating to the sale or exchange of self-created musical works), 
step one of the framework we conclude that under traditional tax policy metrics, these provisions are more favorable to taxpayers than is consistent with an objective of accurately measuring income. Accordingly, they properly are considered tax expenditures. We also demonstrate how these R\&D-specific tax expenditures may be magnified through interaction with another tax expenditure, the deferral of U.S. tax on most active foreign income of controlled foreign corporations. ${ }^{16}$

For purposes of this discussion, R\&D business tax incentives are assumed at least initially to have as their objective correcting a market failure of under-investment in innovative knowledge predicted by economic theory. ${ }^{17}$ This assumption highlights an initial problem: It is difficult to identify research for innovative knowledge that would not be undertaken by companies without the marginal tax incentive. Stated conversely, it is often unclear whether an R\&D incentive will cause additional innovation or will simply be wasted on research that would be conducted even without the tax incentive. This second part of the analysis puts a premium on identifying with some precision the $\mathrm{R} \& \mathrm{D}$ subject to market failure (that is, under-investment) that arguably justifies intervention by means of a tax incentive. This is difficult because there is a gap between the articulation of the economic theory, which does not specify (1) what constitutes innovative knowledge, and (2) the identification of R\&D activity that aims at innovative knowledge and that would plausibly be conducted by the private sector, but in which there is private sector under-investment because of positive spillovers.

Our analysis considers whether the identified business R\&D tax incentive provisions, alone or in combination with other tax expenditure provisions, address private under-investment in innovative knowledge, and whether the tax relief is cost-effective in relation to the revenue loss. Under our current state of knowledge, because of the identification problem described above, we do not have reliable empirical measures of (1) the amount of private under-investment in $\mathrm{R} \& \mathrm{D}$ aimed at innovative knowledge, (2) the welfare loss from such

$\S 1235$ (tax treatment of the sale or exchange of patents), § 1249 (tax treatment of the gain from certain sales or exchanges of patents and other IP to foreign corporations), and $\S 1253$ (tax treatment of transfers of franchises, trademarks, and trade names). For a more comprehensive review of tax provisions affecting IP, see generally Nguyen \& Maine, note 7.

16 IRC § 951(a); see notes 82-98 and accompanying text.

17 See, e.g., note 106 and accompanying text. It is possible that $R \& D$ tax incentives correct other market distortions. For example, the availability of R\&D incentives may reduce the propensity for market concentration in sectors with high $R \& D$ intensity. We thank Professor David Hasen for this observation. We do not explore such other possible effects in this Article. 
under-investment, and (3) the effect of R\&D tax incentives on economic growth and welfare. ${ }^{18}$ We tentatively conclude that a private market failure of under-investment in innovative knowledge has not been sufficiently defined or established to warrant application of the existing R\&D tax incentives to address it.

A possible alternative justification for an $R \& D$ incentive is to foster economic growth through "innovation," as distinguished from compensating for under-investment in R\&D. ${ }^{19}$ However, economic theory fails to provide an operational definition of innovative knowledge and it does not explain sufficiently how knowledge leads to innovation that drives economic growth so as to justify innovation incentives directed at R\&D. Here, as well, we question whether there is sufficient understanding of the process that leads from research to development to commercialization to economic growth to be able to specify an appropriate (and appropriately narrow) target for government intervention that can be achieved with a cost-effective tax incentive. Indeed, factors distinct from $\mathrm{R} \& \mathrm{D}$, such as worker training, workplace designs, and firm organizational processes, are now considered to make a commensurate contribution to innovation. ${ }^{20}$ In essence, we question whether an innovation incentive's cost effectiveness can be established as superior to the alternative potential public uses of the forgone revenues.

The political desire to be perceived as advancing national economic growth is powerful, as highlighted by proposals for an "innovation box" (that is, a lower rate on income intended to be produced from successful R\&D, often also referred to as a "patent box") being aggressively advanced by some in the business community under a ratio-

18 This is not to say that there are not estimates in the literature. The IMF reports that "the private rate of return to business $\mathrm{R} \& \mathrm{D}$ - that is, a firm's extra income from a dollar invested in R\&D—is quite high, typically ranging between 20 and 30 percent. . . .Domestic social rates of return to private $R \& D$ are generally estimated to be two to three times the private return." Int'l Monetary Fund, note 1, at 33-34 (citations and emphasis omitted). These estimates rely on identifying R\&D capital, in the first instance, and, under a growth accounting framework, treating the product of $\mathrm{R} \& \mathrm{D}$ as the residual growth factor in production that is not accounted for by the identifiable inputs (such as labor, capital, and intermediate inputs). Bronwyn H. Hall, Jacques Mairesse \& Pierre Mohnen, Measuring the Returns to R\&D, in 2 Handbook of the Economics of Innovation 1035 (Bronwyn H. Hall \& Nathan Rosenberg eds., 2010). This description hints at the measurement challenges that abound and are acknowledged in the literature. See, e.g., id. at 1073. This article's understated conclusion captures the point that there is at least confidence in the sign of the return: "In spite of the revealed complexity of the problem, we have learned something about the rates of return to R\&D. They are positive in many countries and usually higher than those to ordinary capital. The adjustment costs are also greater than that to ordinary capital." Id.

19 See, e.g., Rod Falvey, Neil Foster \& David Greenaway, Intellectual Property Rights and Economic Growth, 10 Rev. Dev. Econ. 700, 712 (2006).

20 See, e.g., OECD, note 8, at 17; Modica \& Neubig, note 8, at 7-11. 
nale that it is necessary to engage in an intercountry tax competition for R\&D activity. ${ }^{21}$ Our analysis of the innovation box "output" incentive is that it is poorly designed to achieve that end and would be inferior to public-directed research grants or even a tax credit input incentive as a mechanism to retain and attract international human capital talent. $^{22}$ It is also inferior to a reduction in tax rates as a taxbased measure to compete for inbound business investment in innovative technologies. The chief attraction of an innovation box is that its adoption would create the appearance of "doing something" to foster growth, but spending scarce revenue to create such an appearance is a poor use of resources.

In evaluating the use of $R \& D$ tax incentives to respond to an uncertain amount of private $R \& D$ under-investment and uncertain prospects for stimulating economic growth, it is important to also take account of nontax regulatory responses, such as patent and other intellectual property (IP) protections for $\mathrm{R} \& \mathrm{D}$, and direct expenditure responses, such as public funding by the military, the National Science Foundation (NSF), and the National Institutes of Health (NIH) of R\&D activity. All of these approaches are used in the United States, but with insufficient policy coordination and prioritization for the use of resources. ${ }^{23}$

In the third step of the framework we use a traditional form of tax expenditure analysis and consider whether the objectives of an R\&D tax incentive would be achieved more effectively through a regulatory response or a direct expenditure grant program administered by agencies with the relevant subject matter expertise. Daniel Hemel and

21 See generally, e.g., Am. Action Forum, Patent Boxes, Technological Innovation \& Implications for Corporate Tax Reform (2016), http://www.americanactionforum.org/research/patent-boxes-technological-innovation-implications-for-corporate-tax-reform/; Peter Merrill, James R. Shanahan, Jr., José Elías Tomé Gómez, Guillaume Glon, Paul Grocott, Auke Lamers, Diarmuid Macdougall, Alina Macovei, Rémi Montredon, Thierry Vanwelkenhuyzen, Alexandru Cernat, Stephen Merriman, Rachel Moore, Gregg Muresan, Pieter Van Den Berghe \& Andrea Linczer, Is It Time for the United States to Consider the Patent Box?, 134 Tax Notes 1665 (Mar. 26, 2012).

22 See notes $171-72$, and accompanying text. Input tax incentives are given in connection with the expenditure side of the R\&D process; output tax incentives provide preferential treatment to income from qualifying R\&D assets or activity. Robert J. Danon, General Report: Tax Incentives on Research and Development, 100A Cahiers de Droit Fiscal Int'l 19 (2015).

23 See Daniel J. Hemel \& Lisa Larrimore Ouellette, Beyond the Patents-Prizes Debate, 92 Tex. L. Rev. 303, 326-67 (2013) (providing a framework for comparing tax and nontax innovation incentives based on different criteria, including whether the incentive is government- or privately-set, is an ex ante or ex post reward, and cost incidence is on the user or involves cross-subsidization). Within the ambit of tax expenditures, David Schizer also surveys different properties of a variety of mechanisms, such as floors, caps, and phaseouts, to limit or target a tax incentive. David Schizer, Limiting Tax Expenditures, 68 Tax L. Rev. 275 (2015). 
Lisa Ouellette usefully point out that different instruments can achieve similar objectives by adjusting design features. ${ }^{24}$ Following their framework, we argue that weaknesses in specifying the objective for an innovation incentive should bias the choice of instrument away from an open-ended privately set incentive that principally benefits product development and toward an individualized government-set incentive incorporating peer review and a budget constraint that is directed at basic $R \& D$ and $R \& D$ subject to experimental risk. While the features of peer review and a budget constraint can be incorporated into a tax incentive, it may be more cost-effective to use longestablished grant procedures of independent agencies such as NSF and NIH and public expenditure funding.

A clear recommendation for further analysis is whether R\&D tax incentives are cost effective generally or whether, like in Germany, resources should be directed to support human capital development more broadly, including investment in education, and funding for university, nonprofit, and government research (with public disclosure of research results). ${ }^{25}$ If $\mathrm{R} \& \mathrm{D}$ tax incentives are to be retained, analysis should be undertaken to determine whether design improvements increase their efficiency. Based on our analysis an initial list of potential improvements should include:

- Narrowing the R\&D eligibility for tax benefits to speculative $\mathrm{R} \& \mathrm{D}$ for which private sector knowledge is superior to that held in governments and universities.

- Limiting tax incentives to U.S.-performed R\&D.

- Targeting the tax benefit to small- and medium-sized enterprises that otherwise would have difficulty financing risky $R \& D$.

- Using credits instead of deductions, including possibly refundable credits for small- and medium-size enterprises.

\section{U.S. Income Taxation of R\&D}

\section{A. R\&D Expenditure}

Classifying activity as $R \& D$ is a more difficult question than appears at first blush. The largest component of $\mathrm{R} \& \mathrm{D}$ expenditure is wages and benefits. ${ }^{26}$ But whose wages contribute to the creation of innovative knowledge?27 Is it only the scientist or inventor or re-

\footnotetext{
24 Hemel \& Ouellette, note 23, at 307-09.

25 See, e.g., OECD, Higher Education in Regional and City Development: Berlin, Germany 14 (2010), https://www.oecd.org/edu/imhe/46006840.pdf.

26 See notes 34-35 and accompanying text.

27 The wages to be included in costs eligible for the research credit are a source of dispute, particularly in relation to what constitutes direct supervision or support of qualified
} 
searcher? Recent work on innovation would support a broader reach. ${ }^{28}$ Is it helpful to think about what income R\&D produces? The output from $R \& D$ expenditures often is unclear.

The output from $R \& D$ arguably is a return to intellectual capital, ${ }^{29}$ sometimes manifest in legally protected IP or other property or rights developed as a result of successful R\&D activity. But often this return is embedded in income from the sale of non-IP property, goods, or services that incorporate a right to or benefits from an intangible derived from $R \& D .{ }^{30}$ It also is possible that multiple IP legal regimes protect the same product (for example, a software program may be protected by both a copyright and a patent). ${ }^{31}$ Not all successful R\&D results in separately identifiable property, and determining whether an expenditure that arguably improves an existing consumer or intermediate product may be classified as R\&D (even under the expansive U.S. definition of R\&D described below ${ }^{32}$ ) is a daunting line-drawing exercise.

A second reason why $R \& D$ output is difficult to identify is the time lag between R\&D activity and a determination whether it results in a property right, product, or service with a positive return. This time lag can make identification of a return difficult in concept and in practice and bedevils efforts to establish reliable metrics for when R\&D is successful. ${ }^{33}$ Moreover, an R\&D expenditure that initially is "unsuccessful," whether in terms of the research objective or commercially, may nonetheless result in an advance in innovative knowledge. This knowledge may or may not later be used in projects that yield advances in other knowledge, processes, or practical applications and even commercial success.

In addition to the difficulty of assigning $R \& D$ income to particular property and the problem of dealing with "unsuccessful" $R \& D$, there

research activities. See U.S. Gov't Accountability Off., GAO-10-136, The Research Tax Credit's Design and Administration Can Be Improved 28-29 (2009), http://www.gao.gov/ new.items/d10136.pdf.

28 Noninnovative property accounts for over $45 \%$ of knowledge-based capital. Modica \& Neubig, note 8, at 8; see also David P. Lepak, Ken G. Smith \& M. Susan Taylor, Value Creation and Value Capture: A Multilevel Perspective, 32 Acad. Mgmt. Rev. 180, 180-81 (2007).

29 See generally Cong. Budget Office, note 1, at 15-16.

30 See Stephen E. Shay, J. Clifton Fleming, Jr. \& Robert J. Peroni, Designing a 21st Century Corporate Tax-An Advance U.S. Minimum Tax on Foreign Income and Other Measures to Protect the Base, 17 Fla. Tax Rev. 669, 695-96 (2015) (observing that income categorization permits bundling of returns to IP with returns from sales of goods).

31 See Nguyen \& Maine, note 7, at 51-59 (discussing the bundling of IP rights).

32 See notes $54-55$ and accompanying text.

33 The problem of lag from expenditure to innovation and from innovation to commercialization also is recognized as a measurement problem in economic modeling. See Hall et al., note 18, at 1048 ("Often only contemporaneous [R\&D] stocks are used in estimation, because of the shortness of available time-series of R\&D expenditures.”). 
is a third reason why $R \& D$ returns are difficult to identify. An $R \& D$ expenditure is largely for the cost of labor. Historically, only $10 \%$ to $13 \%$ of business expenditure for R\&D internationally was for plant and equipment. ${ }^{34}$ The largest portion of research expenses for the U.S. R\&D tax credit is for services (between 65\% for the 2012 regular R\&D credit and $71 \%$ for the alternative credit). ${ }^{35}$

It is often assumed that $\mathrm{R} \& \mathrm{D}$ expands knowledge, but we do not know when new knowledge contributes to innovation, nor do we know the mechanism that transforms innovation into economic growth. ${ }^{36}$ Even if R\&D encompasses all additions to knowledge, and even if $R \& D$ overwhelmingly consists of expenditures on labor, it is very difficult to determine when labor should be classified as R\&D. For example, is R\&D limited to scientists or should it include the workers who support them and those who directly and indirectly supervise? Do they also contribute to the transformation of new knowledge into innovation ${ }^{37}$ In short, designing an $\mathrm{R} \& \mathrm{D}$ tax incentive that is broad enough to encompass all input expenditures that contribute to innovative knowledge but that avoids the wastefulness of overbreadth is a daunting problem. This demands the disaggregation of R\&D expenses into relevant subcategories of basic, experimental, and applied research that also satisfy standards of novelty and experimental risk. This is very difficult to accomplish, particularly with respect to $\mathrm{R} \& \mathrm{D}$ that relates to intangibles embedded in intermediate goods and processes. ${ }^{38}$

\footnotetext{
34 Bronwyn Hall \& John Van Reenen, How Effective Are Fiscal Incentives for R\&D? A Review of the Evidence, 29 Res. Pol'y 449, 450 (2000). In 2013, U.S. gross domestic expenditure on R\&D was $2.79 \%$ of GDP. OECD, Science, Technology and Industry Outlook 444 (2014), http://www.oecd.org/sti/oecd-science-technology-and-industry-outlook-19 991428.htm.

35 See Internal Revenue Serv., Table 1: Corporations Claiming a Credit for Increasing Research Activities on Form 6765 (Selected Items, by Sectors, Tax Year 2012), SOI Tax Stats-Corporation Research Credit (last updated Mar. 12, 2015), https://www.irs.gov/pub/ irs-soi/12co01rsrchcr.xls; see also Eurry Kim, The Credit for Increasing Research Activities: Statistics from Tax Years 2004-2005, 2008 Statistics of Income Bull. (Publ'n 1136) 182, 187, https://www.irs.gov/pub/irs-soi/04-05crreac.pdf. The 2012 amounts paid for qualified services are $65 \%$ of the qualified research expenses for the regular credit (line 5 divided by line 9 of Form 6765) and $71 \%$ of the qualified research expenses for the alternative credit (line 24 divided by line 28 of Form 6765).

36 See the discussion of innovation in the text accompanying notes 133-35.

37 See, e.g., Gov't Accountability Off., note 27, at 28-29.

38 See Hansson \& Brokelind, note 1 at 186 ("The reason for stimulating R\&D is that too little $R \& D$ is produced by private enterprises because their private return is lower than the social return. . . Ideally, the incentive should bridge this gap. . . Unfortunately, it is hard, if not impossible, to evaluate the effect an incentive has on the gap between social and private returns.”); see also Harry Grubert \& Rosanne Altshuler, Fixing the System: An Analysis of Alternative Proposals for the Reform of International Tax, 66 Nat'l Tax J. 671, 706 (2013) (generally describing the difficulties of disaggregation that are presented by intangibles); see also Lawrence Lokken, The Sources of Income from International Uses and
} 
When U.S. policymakers talk about increasing innovation they often are talking about granting tax incentives. ${ }^{39}$ The benefit of R\&D incentives is a lower effective tax rate, at least for taxpayers that can take advantage of the tax benefit. It is impossible, however, to make a precise determination of whether the lower tax rate is confined to income that in fact derives directly or indirectly from $R \& D$ inputs, because little effort is made to limit the $R \& D$ incentives to $R \& D$ originated returns (even assuming that such returns can be identified). It is difficult to closely identify the relationship between an input R\&D tax benefit, such as the $\S 174$ deduction or the $\S 41$ research credit, and the income ultimately attributable to the expenditure that receives the benefit. It also is especially problematic to design a benefit that targets effectively income that is an output of $R \& D$, such as required for a patent or innovation box. ${ }^{40}$ In sum, it often is difficult to actually identify which expenditures are for "R\&D" (however defined), and what portion of an economic return is attributable to R\&D as distinct from other inputs. Nevertheless, patent box proposals routinely rely on favorable treatment of a residual return, after returns to all other factors, as a proxy for income attributable to intangibles. ${ }^{41}$ This amounts to a de facto tax rate cut for all benefitted firms with excess returns regardless of the extent to which the returns result from $\mathrm{R} \& \mathrm{D}$.

To date, the United States has largely limited its explicit R\&D tax incentives to incentives for expenditures on $\mathrm{R} \& \mathrm{D}$ inputs. As described below, ${ }^{42}$ however, the interaction of intangible development with deferral under the U.S. international tax system is similar in effect to an output incentive that, while not targeted at intangible income, may disproportionately benefit intangible income. This deferral-linked incentive is, however, even less targeted at innovative knowledge than an innovation box.

Dispositions of Intellectual Property, 36 Tax L. Rev. 233, 242-43 (1981); Susan C. Morse, Revisiting Global Formulary Apportionment, 29 Va. Tax Rev. 593, 623-24 (2010); Wolfgang Schön, International Tax Coordination for a Second-Best World (Part II), World Tax J., Feb. 2010, at 65, 91-93.

39 White House, note 6, at 21; Kat Lucero, Lawmaker Continues Push for U.S. Innovation Box Proposal, 82 Tax Notes Int'l 770 (May 23, 2016) (Representative Boustany continues to press for lower taxes on profits tied to U.S. patents and intellectual property through innovation box proposal).

40 The scope of the income benefitted in patent box regimes testifies to the problem. See generally Danon, note 22, at 37-42. Some parts of the U.S. business community have promoted proposals for a lower tax rate for patent box (or innovation box) income. See, e.g., Merrill et al., note 21, at 1665-66.

41 See id. at 1671.

42 See Subsection II.C.1. 


\section{B. U.S. R\&D Tax Incentives}

\section{Deduction for $R \& D$ expenditures}

Generally, for U.S. tax purposes, business expenditures associated with creating or improving an asset with a useful life that extends beyond a year are capitalized and taken into account under the depreciation or amortization rules. ${ }^{43}$ "[R]esearch or experimental expenditures ... incurred ... in connection with [a] trade or business," however, may be deducted in the year incurred. ${ }^{44}$ These R\&D deductions are not recaptured if a resulting technology is sold. ${ }^{45}$

Alternatively, taxpayers may use a so-called deferred expense method to capitalize and recover ratably over sixty months or longer research expenditures incurred in a trade or business that (1) are chargeable to a capital account (but not for depreciable property or property subject to depletion), and (2) do not give rise to property that has a determinable useful life. ${ }^{46}$ Under the deferred expense method, amortization begins in "the month in which the taxpayer first realizes benefits from the expenditures." 47

In addition, $\S 59(\mathrm{e})$ allows taxpayers to elect to amortize their research expenditures over a period of ten years. ${ }^{48}$ This election can be more favorable than the deferred expense method under $\S 174(\mathrm{~b})$ for taxpayers who want to extend the period of recovery. This is so because the $\S 59(\mathrm{e})$ recovery period, which begins when the expenditures are incurred rather than when the benefits of the expenditure are first obtained, is ten years rather than five years. ${ }^{49}$

43 IRC $\S \S 167,168,197,263$; Reg. $§ 1.263(a)-4(b)$, (f).

44 IRC § 174(a); see also Snow v. Commissioner, 416 U.S. 500, 504 (1974) (interpreting $\S 174$ as extending broadly to research expenditures incurred with an intent to make a profit, regardless of actual realization).

45 Rev. Rul. 85-186, 1985-2 C.B. 84, revoking Rev. Rul. 72-528, 1972-2 C.B. 481 (requiring recapture). The deduction for $\mathrm{R} \& \mathrm{D}$ expenses under $\S 174$ in certain circumstances is an alternative minimum tax (AMT) preference item for individuals but not for corporations. Individuals who own pass-through business entities and do not materially participate in the business must capitalize and amortize $\S 174 \mathrm{R} \& \mathrm{D}$ costs over ten years when calculating AMT liability. IRC $\S 56(\mathrm{~b})(2)(\mathrm{A})(\mathrm{ii})$.

46 IRC $\$ 174(\mathrm{~b})$. For details of the deferred expense method, see Kendall B. Fox, Jim Bowers, James R. Shanahan \& Joseph F. Maselli, Research and Development Expenditures, 556-2d Tax Mgmt. Portfolio (BNA) § V.C. (2016). While the need for the election has decreased with the extension of the net operating loss carryover period, taxpayers nonetheless may choose this alternative for a variety of reasons and presumably do so when they believe it is advantageous for tax purposes.

47 Reg. $\$ 1.174-4(\mathrm{a})(3)$.

48 IRC $\S \S 59(\mathrm{e}), 174(\mathrm{f})(2)$. The $\S 59(\mathrm{e})$ election is available to corporations even though the $\S 174$ expense has not been a corporate AMT preference item since 1986.

49 For taxpayers with foreign operations and domestic net operating losses, which generally are large corporate taxpayers, the longer amortization period allowed under $\S 59(\mathrm{e})$ may be favorable because it can mitigate the buildup of an overall foreign loss and/or 
The expenditures covered by $\S 174$ include R\&D costs incurred by the taxpayer directly and by a service provider performing $R \& D$ on behalf of the taxpayer. ${ }^{50} \mathrm{R} \& \mathrm{D}$ expenditures may be deducted only to the extent that the amount is reasonable under the circumstances. ${ }^{51}$

To the extent an R\&D expenditure is allowed as a deduction in advance of when it otherwise could be taken into account under normal tax accounting capitalization standards, it is classified as a tax expenditure. ${ }^{52}$ The Joint Committee estimate of the tax expenditure amount from $\S 174$ is $\$ 28.3$ billion over the five-year period of fiscal years 2015 through 2019.53

The $\S 174$ term "research or experimental expenditures" is generally defined in the regulations to mean expenditures that represent research and development costs in the experimental or laboratory sense. ${ }^{54}$ This often-quoted language potentially misleads regarding the scope of expenditures that come within the $\S 174$ expensing rule. The regulations provide: "Expenditures represent research and development costs in the experimental or laboratory sense if they are for activities intended to discover information that would eliminate uncertainty concerning the development or improvement of a product." 55

Another signal feature of the $\S 174$ expensing rule is that it is not limited to R\&D performed in the United States. Accordingly, R\&D performed through a foreign branch or by a foreign service provider is eligible for expensing.

To accommodate pressures along various margins from industry, Treasury and the IRS have indirectly expanded the definition of $\mathrm{R} \& \mathrm{D}$. As one example cited by commentators, changes to the regulations' application of the "uncertainty" test were promulgated so that

otherwise increase a foreign tax credit limitation as a result of a reduced allocation of R\&D to foreign income.

50 Reg. $\$ 1.174-2(\mathrm{a})(10)$.

51 IRC $\$ 174(\mathrm{e})$.

52 See Staff of Joint Comm. on Tax'n, 114th Cong., JCX-141R-15, Estimates of Federal Tax Expenditures for Fiscal Years 2015-2019, at 6 (Comm. Print 2015).

53 See id. at 29 tbl.1. The Joint Committee estimate of the amount of a tax expenditure is a static estimate of tax that would be paid if the provision were not in place and the taxpayer used the best available alternative tax treatment of the item. Id. at 18. Treasury also treats R\&D expensing as a tax expenditure. See Off. Mgmt. \& Budget, Analytical Perspectives Fiscal Year 2017, at 228 tbl.14-1, https:/www.whitehouse.gov/sites/default/ files/omb/budget/fy2017/assets/spec.pdf. The Treasury estimate for the ten-year budget period of 2015-2024 is $\$ 73.41$ billion. Id. The Treasury approach differs from that of the Joint Committee in that it assumes that no alternative tax expenditure is available to benefit the item. See Joint Committee, supra, at 18-19. In either case, the tax expenditure estimate is not the same as a revenue estimate in that it does not take into account behavioral responses. Id. at 13; Off. Mgmt. \& Budget, supra, at 226.

54 Reg. § 1.174-2(a)(1).

55 Id. 
knowledge that a product development project would be successful would not prevent product design from qualifying as research. ${ }^{56}$ This expanded permissible deductions under $\S 174$, but it is unclear whether it has reduced the uncertainty arising from boundary issues (in fact, one could plausibly argue that it makes the boundary issues even murkier). ${ }^{57}$ More important for our discussion, this approach takes the concept of $R \& D$ far away from the reach of any likely market failure of under-investment in $\mathrm{R} \& \mathrm{D}$, thus undercutting that economic rationale for the $\S 174$ deduction.

\section{Credit for Increasing Research Activities}

The United States enhances the treatment of $R \& D$ expenses for those who choose to forgo the $\S 174$ deduction and claim a $20 \%$ R\&D tax credit that attempts to target "incremental" R\&D. ${ }^{58}$ The definition of R\&D expense for the credit is the same as that for $\S 174$ expensing, with three additional requirements: (1) The research must be for discovering information that is technological in nature and intended to be useful in the development of a new or improved business component of the taxpayer; (2) substantially all of the research activity must constitute a process of experimentation; and (3) the experimentation must relate to a permitted purpose. ${ }^{59}$ There are various exclusions, including for research relating to style or taste, ${ }^{60}$ performed after commercial production (but of a particular product), ${ }^{61}$ and to adapt a product for a particular customer. ${ }^{62}$

The "traditional" R\&D tax credit is $20 \%$ of "qualified research expenses" above a base amount.63 The base amount is calculated by multiplying the taxpayer's average gross receipts for the four prior

56 See Fox et al., note 41, § II.B.1 (citing F.S.A. 200125019 (June 22, 2001) (holding that design and improvement of athletic footwear may qualify as $\S 174 \mathrm{R} \& \mathrm{D}$ to the extent attributable to eliminating uncertainty in the development or improvement of the product)).

57 Gov't Accountability Off., note 27, at 26-28 (identifying areas of contention regarding scope of allowable $R \& D$ expense for $R \& D$ credit; some also are applicable to $\S 174$ expensing).

58 IRC $\S 41$; see note 15 . A taxpayer may claim a deduction and elect a reduced credit. IRC $\S 280 \mathrm{C}(\mathrm{c})(3)$.

59 IRC § 41(d)(1), (3); see David L. Cameron, Research Tax Credit: Statutory Construction, Regulatory Interpretation and Policy Incoherence, 9 Computer L. Rev. \& Tech. J. 63, 162 (2004) (concluding that the requirement that research be technological imposes little substantive limitation in addition to $\S 174$, and that the final regulations' definition of "process of experimentation" is so "vacuous" as to "render it largely one of form and not substance").

60 IRC $\S 41(\mathrm{~d})(3)(\mathrm{B})$.

61 IRC $\S 41(\mathrm{~d})(4)(\mathrm{A})$.

62 IRC $\S 41(\mathrm{~d})(4)(\mathrm{B})$.

63 IRC $\S 41(a)(1)$. 
years by a "fixed-base percentage." 64 The base amount, however, cannot be less than $50 \%$ of the taxpayer's qualified research expenses for the taxable year. ${ }^{65}$ The fixed base percentage is the ratio of research expenses to gross receipts for the years 1984 through 1988, ${ }^{66}$ for taxpayers in existence at the time.

A somewhat different calculation applies to payments for "basic research" made to a qualified research organization. ${ }^{67}$ The credit is $20 \%$ of basic research payments above a base amount that is calculated separately in respect of payments to qualified research organizations. These payments generally are payments that would be deductible as charitable deductions and are made to, generally, universities and certain tax-exempt research organizations. "Basic research" is defined as "any original investigation for the advancement of scientific knowledge not having a specific commercial objective." 68

An alternative simplified $\mathrm{R} \& \mathrm{D}$ tax credit is $14 \%$ of qualified research expenses above a base equal to $50 \%$ of the average qualified research expenses for the prior three taxable years. ${ }^{69}$ The effect of having the credit determined on a moving average base of $R \& D$ expenditure is that additional $\mathrm{R} \& \mathrm{D}$ expense in the current year decreases the benefit of the credit in future years. The effective rate of the tax benefit therefore is less than the nominal rate. ${ }^{70}$ Once used, the alternative simplified credit applies to all succeeding years unless the taxpayer obtains IRS consent for a change. ${ }^{71}$

Qualified research expenses include both in-house research expenses and contract research expenses. ${ }^{72}$ Generally only $65 \%$ of payments for qualified research by the taxpayer to an outside person are

\footnotetext{
64 IRC $\S 41(\mathrm{c})(1)$.

65 IRC $\S 41(\mathrm{c})(2)$.

66 IRC $\S 41(\mathrm{c})(3)(\mathrm{A})$.

67 IRC $\S 41(a)(2)$, (e). This is referred to as the "university basic research credit." The 2012 amounts paid for basic research are less than $0.5 \%$ of the qualified research expenses for the regular credit (line 1 divided by line 9 of Form 6765) and the alternative (line 19 divided by line 28 of Form 6765). See IRS, Statistics of Income 2012: Corporation Research Credit tbl.1, https://www.irs.gov/uac/soi-tax-stats-corporation-research-credit.

68 IRC $\S 41(\mathrm{e})(7)(\mathrm{A})$.

69 IRC $\S 41(\mathrm{c})(5)$. The rate is reduced to $6 \%$ if a taxpayer has no qualified research expenses in any one of the three prior taxable years. IRC $\S 41(\mathrm{c})(5)(\mathrm{B})(\mathrm{ii})$.

70 See Staff of Joint Comm. on Tax'n, 112th Cong., JCX-45-11, Tax Incentives for Research, Experimentation, and Innovation 14-16 (Comm.Print 2011), https://www.jct.gov/ publications.html?func $=$ startdown $\&$ id $=4358$.

71 IRC $\S 41(\mathrm{c})(5)(\mathrm{C})$. This Article does not consider the specialized credit limitations for energy research consortium research. See IRC $\S 41(a)(3)$.

72 IRC $\S 41(b)(1)$.
} 
included as contract research expenses. ${ }^{73}$ To qualify for the credit, the R\&D activity must be performed in the United States. ${ }^{74}$

The $R \& D$ tax credit is a part of the general business credit, ${ }^{75}$ and does not reduce the AMT liability of corporations or individuals. ${ }^{76}$ The credit is overwhelmingly claimed by firms with assets of $\$ 50$ million or more. ${ }^{77}$

The $\mathrm{R} \& \mathrm{D}$ credit was temporary for many years, ${ }^{78}$ but was made permanent at the end of 2015, eliminating the sunset date. ${ }^{79}$ The most important reason the $\mathrm{R} \& \mathrm{D}$ credit had been temporary was the revenue cost of making the credit permanent. It was perennially on the list of tax extenders and each time was extended, though in some years substantially after the date the credit expired. ${ }^{80}$ Businesses regularly criticized the temporary nature of the credit on the ground that the uncertainty hindered their business planning. ${ }^{81}$

73 IRC $\S 41(b)(3)(A)$. As defined in $\S 41(b)(2)$, "in-house" research consists of wages paid to an employee engaging in qualified research or engaging in the direct supervision or direct support of qualified research activities; amounts paid for supplies, including tangible property other than land or depreciable property, used in the conduct of qualified research; and generally amounts paid to another person for the right to use computers in the conduct of qualified research. Under $\S 41(\mathrm{~b})(3)$, "contract research" generally consists of $65 \%$ of amounts paid to any nonemployee for qualified research. The limit increases to $100 \%$ for payments to eligible small businesses, universities, and federal laboratories for qualified energy research.

74 IRC $\S 41(d)(4)(F)$.

75 IRC \& 38(b)(4).

76 See IRC $\$ 56$. This Article does not discuss the effects of the limitations on the business tax credit generally. See IRC $\S 38(\mathrm{c})$; Rashkin, note 1, at 1067 (recommending elimination of the business tax credit limits on the $R \& D$ credit). $R \& D$ expensing is not an alternative minimum tax preference item for corporations but is for individuals in certain circumstances. See IRC $\S 174(\mathrm{~b})(2)$; see notes 45 and 48.

77 In fiscal year 2008, firms with assets of $\$ 50$ million or more claimed $87 \%$ of the R\&D credits claimed. See Joint Committee, note 70, at 13 tbl.3.

78 See IRC $\S 41(\mathrm{~h})$.

79 Protecting Americans from Tax Hikes Act of 2015, Pub. L. No. 114-113, § 121(a)(1), 129 Stat. 2242, 3049-52. The legislation also allows small businesses to use the credit against payroll taxes. IRC $\S 41(\mathrm{~h})$.

80 See, e.g., Tax Increase Prevention Act of 2014, Pub. L. No. 113-295, § 111(a), 128 Stat. 4010, 4014 (extending credit from end of 2013 to end of 2014). One consequence of retroactive extensions of the effective date was that businesses' year-end and quarterly financial statements issued during periods that the credit had expired could not reflect the value of the credit as a tax benefit for the period during which the credit was not in effect. When the credit was retroactively reinstated, as has been the practice several times in recent years including 2015, subsequent financial statements took account of the tax benefit for those earlier periods.

81 See, e.g., Rashkin, note 1, at 1069. 


\section{Interaction with International Tax Rules}

To fully evaluate the existing system of U.S. R\&D incentives, it is necessary to examine how those incentives interact with the U.S. international income tax regime.

\section{Deferral and Transfer Pricing}

A U.S. corporation generally is not taxed currently on the earnings and profits (E\&P) of a controlled foreign corporation (CFC) in an active business until the CFC distributes cash or other property to it (or it sells the stock of the CFC). ${ }^{82}$ This is referred to as the deferral privilege.

U.S. firms with multinational businesses in recent decades have employed strategies to enhance deferral by shifting to foreign affiliates in low-tax jurisdictions intangible property that often will have benefitted from R\&D incentives. The tax objective is to justify income allocations to low-taxed CFCs that maximize the benefit of deferral of foreign income from current U.S. income taxation. ${ }^{83}$

82 IRC $\S 301$ (c). A CFC is a foreign corporation the stock of which is more than $50 \%$ owned, by vote or value, directly, indirectly, or by attribution, by one or more "United States shareholders." IRC $\S 957($ a). A "United States shareholder" is a U.S. person that owns, directly, indirectly, or by attribution, $10 \%$ or more of the voting power of the foreign corporation's stock. IRC $\S 951(\mathrm{~b})$.

A CFC is subject to foreign base company income rules under subpart $\mathrm{F}$ that can cause certain earnings to be included currently in income of a U.S. shareholder, but those rules are largely inapplicable or avoidable in relation to active business income. See IRC $\S \S 951-965$. Section 956, however, provides an exception to the general rule of deferral. Under that provision, the amount of a CFC's untaxed foreign earnings that is considered to be invested in certain "United States property," including certain U.S. intangible property, is treated as though it was distributed to the CFC's U.S. parent company and included in its income. See IRC § 956(a). In this Article, "U.S. parent" or "U.S. affiliate" refers to a "United States shareholder" as defined in $\S 951(b)$ in relation to the CFC. Under $\S 951(\mathrm{a})(1)(B)$, a U.S. shareholder of a CFC must include in income its allocable portion of previously untaxed earnings attributable to investments made or deemed made "directly or indirectly" by the CFC in U.S. property. The amount of the investment in U.S. property is the average quarterly balance of the CFC's adjusted tax basis in U.S. property, reduced by any liability to which the property is subject. See IRC $\S \S 951,956,959$.

83 The incentive for public companies to pursue this income-shifting strategy is enhanced by the financial accounting standards. Those standards include the affiliated corporate group's consolidated worldwide sales and income in earnings, but permit a U.S. parent company to not take into account the residual U.S. tax on foreign earnings of a foreign affiliate if the U.S. parent company intends to indefinitely reinvest the earnings outside the United States in a manner that will not result in residual U.S. taxation. Under Accounting Principles Board Opinion No. 23 (APB 23), a company is permitted to defer recording income tax expense on foreign E\&P if "sufficient evidence shows that the subsidiary has invested or will invest the undistributed earnings indefinitely." Accounting Principles Board Opinion No. 23 (codified as FASB Accounting Standards Codification (ASC) 74030-25-17). Under this provision, the U.S. parent company must provide evidence of "specific plans of reinvestment of undistributed earnings of a subsidiary which demonstrate that remittance of the earnings will be postponed indefinitely." Id. This accounting treatment 
A well-publicized example is Apple Inc., which shifted substantial amounts of earnings to a nonresident Irish affiliate that apparently paid an effective foreign rate of less than $2 \%$ on these earnings. ${ }^{84}$ Apple relied on a cost-sharing agreement between the parent company and one or more nonresident Irish subsidiaries and a very limited allocation of profit to Irish branches as approved by the Irish Revenue. ${ }^{85}$ Under cost sharing, generally, an affiliate that shares the research costs (and risks) commensurate with the benefits it expects to receive from the research may be treated as owning an undivided interest in the $\mathrm{R} \& \mathrm{D}$ rights produced under the arrangement.

Apple's income shifting related to IP in which its nonresident Irish affiliates claimed to possess rights under the cost-sharing agreement. ${ }^{86}$ The scale of the amounts shifted reflects Apple's size and profitability, though the amounts are substantial on a relative basis as well. Apple, however, is merely one prominent example of such income shifting. Aggregate data shows that income shifting is practiced by numerous multinational firms in connection with deferral. ${ }^{87}$ In addition to the revenue concern that income that should be in the U.S. tax base is being shifted abroad, the reduced level of effective tax on that income also increases the incentive to shift real economic activity and factors of production, in addition to profits, abroad.

While deferral is not normally thought of as an R\&D tax expenditure, ${ }^{88}$ recent work at the Organisation for Economic Cooperation and Development (OECD) and by scholars supports examining the

often is the largest contributor to a lower "book" tax rate than the U.S. federal statutory rate of $35 \%$ (plus relevant state rates) for U.S. multinational companies. See, e.g., Pfizer Corporation, FY 2015 Form 10-K, at 90 (2016), https://www.sec.gov/Archives/edgar/data/ 78003/000007800316000077/pfe-12312015x10kshell.htm (largest reduction from federal rate in rate reconciliation table is for "Taxation of non-U.S. operations").

84 See Offshore Profit Shifting and the U.S. Tax Code-Part 2 (Apple Inc.): Hearing Before the S. Homeland Security \& Govt. Affairs Permanent Subcomm. on Investigations, 113th Cong. 115 (2013), https://www.gpo.gov/fdsys/pkg/CHRG-113shrg81657/pdf/CHRG113shrg81657.pdf (testimony of Stephen E. Shay, Professor, Harvard Law School).

85 Eur. Comm'n, State Aid SA.38373 (2014/C) - Ireland Alleged Aid to Apple § 2.3, ec.europa.eu/competition/state_aid/cases/253200/253200_1582634_87_2.pdf.

86 See Shay Statement, note 84, at 114.

87 See Kimberly A. Clausing, The Effect of Profit Shifting on the Corporate Tax Base, 150 Tax Notes 427, 428 (Jan. 25, 2016). Based on 2006 tax return data, 45.9\% of earnings of U.S. multinationals' controlled foreign subsidiaries that reported positive income and some foreign tax were taxed at a foreign effective rate of less than $10 \%$. Grubert \& Altshuler, note 38, at 699 tbl.3. Less than one quarter of these foreign subsidiaries' income was taxed at an effective foreign rate of $30 \%$ or more, and $53.9 \%$ of these foreign subsidiaries' income was taxed at a foreign effective rate of $15 \%$ or less. Id.

88 Both Treasury and the Joint Committee Deferral classify deferral as a tax expenditure. See Joint Committee, note 52, at 29 tbl.1; Off. Mgmt. \& Budget, note 53, at 228 tbl.141. For a comprehensive discussion of why deferral should be classified as a tax expenditure and a cost-benefit analysis of deferral as a tax subsidy, see Fleming \& Peroni, note 3, at $528-41$. 
full array of $R \& D$ incentives on an integrated basis that takes into account all of the effects of the tax system, including the international tax rules, of which deferral is an important component. ${ }^{89}$

The interaction of U.S. international tax rules with R\&D tax incentives is complicated. The $\S 174$ deduction is allowed for qualifying $\mathrm{R} \& \mathrm{D}$ wherever performed. The $\S 41$ tax credit is allowed only for domestic R\&D. ${ }^{90}$ Successful domestic R\&D, however, may give rise to an IP right, such as a patent, that can be registered separately in jurisdictions around the world and thereby give rise to both domestic and foreign IP rights and income. It has been commonplace to transfer foreign IP rights to a low-taxed CFC, by license, cost sharing, or otherwise, and for the CFC to earn low-taxed foreign income. This strategy works under current law even if the foreign IP right derives from R\&D that has benefitted from a U.S. tax incentive.

As noted above, taxpayers also have shifted U.S. IP rights to CFCs in low-tax jurisdictions through licenses or cost sharing. As one example, the Staff of the Senate Permanent Subcommittee on Investigations found that Microsoft transferred rights to software developed in the United States to a CFC operating in Puerto Rico, so that digital and physical copies could be made for sale to customers in the United States with the sales profits being taxed only in Puerto Rico. ${ }^{91}$ In fiscal year 2011, Microsoft's Puerto Rican subsidiary booked over $\$ 4$ billion of operating income for financial statement purposes and paid under $1 \%$ in tax (after paying $\$ 1.9$ billion in cost-sharing payments). ${ }^{92}$

Although income shifted to a low-taxed CFC with respect to a foreign IP right is likely to derive at least in part from the foreign jurisdiction under the laws of which the IP right is enforced. However, this does not mean that the income is not also earned in part in the United

89 See OECD, note 8, at 128 ("A key message is that international tax policies and crossborder tax planning should be taken into account when measuring the tax burden on $\mathrm{R} \& \mathrm{D}$ ...., and in assessing the design and behavioral effects of R\&D tax incentives."); Noam Noked, Integrated Tax Policy Approach to Designing Research \& Development Tax Benefits, 34 Va. Tax Rev. 109, 112 (2013) (concluding that the availability of income shifting may mitigate investment disincentives under the current income tax system and changes to the ability to shift IP income may change incentives to invest in domestic R\&D).

90 See note 74 and accompanying text. Domestic R\&D that is offset by a cost-sharing payment under a cost-sharing agreement nonetheless qualifies for the R\&D tax credit.

91 Offshore Profit Shifting and the U.S. Tax Code-Part 1 (Microsoft \& Hewlett-Packard): Hearing Before the S. Homeland Security \& Gov't Affairs Permanent Subcomm. on Investigations, 113th Cong. (2013) (Exhibit 1: Memorandum from Sen. Carl Levin, Chairman, and Sen. Tom Coburn to Subcommittee Members, Offshore Profit Shifting and the U.S. Tax Code 20-22 (Sept. 20, 2012), https://www.gpo.gov/fdsys/pkg/CHRG_112shrg760 71/pdf/CHRG-112shrg76071.pdf. Intangible rights with respect to the software lay behind the Puerto Rican operation's claim to $47 \%$ of the operating profit on the U.S. sales. Id at 21.

92 Id. 
States if the $R \& D$ activity underlying the foreign IP right was performed in the United States.

In the case of U.S. intangibles, as a tax planning matter, it is important that the U.S. rights that are within the scope of the U.S. antideferral rules for investments in U.S. property have a zero basis. Otherwise, the holding of the intangible asset will trigger an inclusion of untaxed E\&P in a U.S. shareholder's income under $\S 956.93$

There is a longstanding debate over whether trademarks and socalled market intangibles are covered by the $\S 956$ rules because of the contrast between the $\S 956(\mathrm{c})(1)(\mathrm{D})$ and the $\S 936(\mathrm{~h})(3)(\mathrm{B})$ definitions of an intangible. ${ }^{94}$ There are other respects in which U.S. taxpayers may take positions that allow CFCs to hold U.S. intangible assets without running afoul of the $\S 956$ rules that carry varying degrees of risk. ${ }^{95}$

The bottom line is that it is feasible and indeed common to achieve very low rates of tax on income earned by a CFC using IP rights that benefited from U.S. tax incentives for R\&D. The combination of these low rates and deferral has the effect of lowering the after-tax cost of the R\&D input.

The deferral tax expenditure is a general output incentive directed at business conducted outside the United States. It is not designed as a domestic R\&D incentive. ${ }^{96}$ Nonetheless, while not targeted at the externalities that presumably are the object of the input R\&D incentives, deferral does disproportionately benefit R\&D-intensive indus-

93 See IRC $\S 956(a),(c)(1)(D)$. The amount of U.S. property is measured with reference to asset basis rather than fair market value. IRC $\S 956(a)$. For this reason, taxpayers' cost sharing with respect to U.S. intangibles is usually designed to be for self-developed intangibles so that the $\S 174$ deduction can be used to avoid capitalization of development costs and the resulting basis in a U.S. asset. If the cost sharing covers a purchased U.S. intangible, the $\S 956$ rules will be triggered because the foreign affiliate will be considered to jointly own an asset that has a positive U.S. tax basis. Many taxpayers do not focus on this issue and the authors are not aware that the issue has ever been audited. As one example of a potentially dangerous foot fault, a company that has a cost-sharing arrangement covering U.S. intangible rights should not make a $\$ 59$ election to amortize R\&D expenditures that are covered by the cost-sharing election if the basis would be considered in a U.S. intangible.

94 See, e.g., Ken Brewer \& Bruce Reynolds, Some Intangibles May Be Untouched by U.S. Internal Revenue Code Section 956, 21 Tax Notes Int'l 1797 (Oct. 16, 2000); Paul K. Marineau, What Lies Beneath Section 956(c)(1)(D): Does an Intangible Property Right Constitute an Investment in U.S. Property?, 9 BYU Int'l L. \& Mgmt. Rev. 81, 90 (2012). The $\S 936(\mathrm{~h})(3)(\mathrm{B})$ definition of intangible property includes trademarks, trade names, and brand names, while the $\S 956(\mathrm{c})(1)(\mathrm{D})$ definition makes no mention of those items but does include rights "similar" to copyrights.

95 For example, it may be possible to hold an active intangible in a company with no E\&P and rely on $\S 954(c)(6)$ to strip out the return to the intangible.

96 See U.S. Treasury Dep't, The Deferral of Income Earned Through U.S. Controlled Foreign Corporations: A Policy Study 3 (2000), https://www.treasury.gov/resource-center/ tax-policy/Documents/Report-SubpartF-2000.pdf. 
tries, such as the pharmaceutical and information technology industries, that have substantial intangible property that can be "moved" offshore by transfer or license. Deferral also disproportionately benefits the largest-sized firms (such as those with over $\$ 50$ million in assets) that also are the largest beneficiaries of the R\&D tax credit. $^{97}$

The tax treatment of intangible property is the link between the R\&D input subsidies and the deferral of U.S. income tax on foreign business income. For example, if R\&D expenditures were capitalized, instead of currently deducted, U.S. intangibles would have a positive tax basis and the $\S 956$ anti-deferral "investment in U.S. property" rules would apply to restrict this element of income stripping. ${ }^{98}$

\section{Apportionment of R\&D Expenses to Foreign Income}

A U.S. taxpayer that earns foreign income from international operations and that has currently deductible $\S 174 \mathrm{R} \& \mathrm{D}$ expense must allocate and apportion the expense between foreign-source and U.S.source income for purposes of the foreign tax credit limitation. ${ }^{99}$ For a taxpayer in an excess-credit position, the reduction of foreign income by the allocated $R \& D$ deduction has the effect of denying for that year a foreign tax credit against U.S. tax on that amount of income. Accordingly, taxpayers that need a greater foreign tax credit limitation (that is, they are in an excess-credit position) prefer to allocate as little R\&D expense as possible to foreign income. The allocation rules are very taxpayer-favorable in this regard and in a range of cases under-allocate R\&D to foreign income.

The taxpayer-favorable $R \& D$ expense allocation and apportionment rules are treated as a tax expenditure by the Joint Committee but not by Treasury. The JCT tax expenditure estimate is relatively small at approximately $\$ 200$ million of revenue loss annually. ${ }^{100}$

There is little empirical evidence on the effect of the taxpayerfavorable rules for allocating $R \& D$ deductions away from foreign income. The most recent Treasury study of R\&D expense allocation rules, which accompanied adoption of final regulations in 1995, does

\footnotetext{
97 See Joint Committee, note 2, at 115 tbl.31.

98 Under current law, capitalization would not cause the $\S 956$ inclusion rules to apply to foreign intangible rights, including those derived in whole or in part from R\&D performed in the United States.

99 See IRC $\S \S 174,864(f)$; Reg. $§ 1.861-17$. The rules for allocating and apportioning R\&D expense are described in Am. Bar Ass'n Tax Sec. Task Force on Int'l Tax Reform, Report of the Task Force on International Tax Reform, 59 Tax Law. 649, 767-71 (2006).

100 Joint Committee, note 52, at 28 tbl.1.
} 
not address the effects of the allocation on R\&D investment. ${ }^{101} \mathrm{We}$ are skeptical that the $R \& D$ deduction allocation rules are a cost-effective $R \& D$ incentive since, like $\S 174$, they are not targeted at R\&D in which there is under-investment.

An effective disallowance of domestic deductions for foreign-allocated R\&D expense would increase the after-tax cost of performing $R \& D$. It is unclear how much it would affect the amount of $R \& D$ investment in the United States. A claim that would raise a serious concern, if true, is that the additional after-tax cost of $R \& D$ resulting from disallowance of deductions for $R \& D$ outlays would trigger a relocation of U.S. knowledge personnel abroad or a preference for foreign over U.S. researchers. The impact of increasing the tax cost of $R \& D$ by allocating $R \& D$ expense to foreign income on the location of $\mathrm{R} \& \mathrm{D}$, however, is an empirical question that is as yet unanswered.102

The risk of other countries attracting $\mathrm{R} \& \mathrm{D}$ personnel or assets is a part of a larger issue, which is the extent to which the United States should respond to international competition for $R \& D$ investment, such as that presented by patent or innovation boxes. ${ }^{103}$ But before turning to the possibility of new $R \& D$ incentives, it is critical to observe that, as demonstrated in the preceding discussion, the United States already provides substantial incentives for R\&D in the form of the $\S 174$ deduction, the $\S 41$ credit, the deferral privilege, and taxpayer-generous $R \& D$ expense allocation rules. ${ }^{104}$ Importantly, the targeting of these incentives is weak and the evidence that they are cost-effective is sparse.

\section{Why Subsidize Research and Development?}

\section{A. Market Failure-Under-investment in R\&D}

Legal discussions of $\mathrm{R} \& \mathrm{D}$ tax incentives generally rely on two premises from the economic literature. The first is the importance of technological innovations to economic growth. ${ }^{105}$ The second is that

101 U.S. Treas. Dep't, The Relationship Between U.S. Research and Development and Foreign Income (May 19, 1995), available at BNA Daily Tax Rep. (May 22, 1995) (stating that the range of uncertainty of the relationship between domestic R\&D and foreign income is large).

102 See Michael J. Graetz \& Rachael Doud, Technological Innovation, International Competition, and the Challenges of International Income Taxation, 113 Colum. L. Rev. 347, 360 (2013) ("extant studies do not indicate whether R\&D tax incentives drive firms' decisions of where to locate R\&D").

103 See notes 21-22 and accompanying text.

104 See Sections II.B and II.C.

105 See, e.g., Graetz \& Doud, note 102, at 348 \& n.1 (citing Robert M. Solow, Technical Change and the Aggregate Production Function, 39 Rev. Econ. \& Stat. 312, 320 (1957)); see also Noked, note 89, at 114. 
$\mathrm{R} \& \mathrm{D}$ that leads to innovative knowledge is under-produced in the absence of government support. ${ }^{106} \mathrm{R} \& \mathrm{D}$ is under-produced because absent government intervention, the knowledge produced by R\&D can be used by other firms (which would increase social welfare), but firms cannot capture the full returns from their investment in the R\&D (which would discourage private investment). ${ }^{107}$

Positive spillovers from (successful) R\&D include rent spillovers and knowledge spillovers. ${ }^{108}$ These spillovers can lead to improved labor productivity and higher wage jobs, which are believed to occur primarily in proximity to where the R\&D is conducted. ${ }^{109}$ For these reasons, countries compete to attract $\mathrm{R} \& \mathrm{D}$ activity within their borders. Some, but not all, countries rely on R\&D tax incentives. ${ }^{110}$ The current vogue among tax havens and, more recently, some larger economies, is to use patent boxes to benefit $\mathrm{R} \& \mathrm{D}$ returns to IP. ${ }^{111}$ Longstanding U.S. input R\&D tax incentives are deductibility for $\mathrm{R} \& \mathrm{D}$ and/or an R\&D tax credit. To date, the United States has not adopted an explicit output incentive, such as a patent or innovation box, though, as discussed above, U.S. international tax rules have much of the effect of an output incentive by reducing the effective tax rate on deferred earnings attributable to intangibles resulting from U.S. R\&D activity. In any event, the same principles should apply for evaluating an output $R \& D$ incentive as for an input $R \& D$ incentive.

106 See, e.g., Graetz \& Doud, note 102, at 349; Hansson \& Brokelind, note 1, at 175-76; Noked, note 89 , at 114 . This view is based on an "incomplete private appropriability" problem. See Paul A. David, Bronwyn H. Hall \& Andrew A. Toole, Is Public R\&D a Complement or Substitute for Private R\&D? A Review of the Econometric Evidence, 29 Res. Pol'y 497, 501 (2000) (referring to the work of R.R. Nelson and Kenneth Arrow); Kenneth J. Arrow, Economic Welfare and the Allocation of Resources for Invention, in The Rate and Direction of Inventive Activity: Economic and Social Factors 609, 621 (Richard Nelson ed., 1962).

107 See Graetz \& Doud, note 102, at 349 (citing the economic literature); see also Noked, note 89, at 115. But see Rashkin, note 1, (criticizing the argument that private returns do not capture the full benefit of $R \& D$ expenditures).

108 Hall et al., note 18, at 1965 (Rent spillovers occur "when a firm or consumer purchases R\&D-incorporated goods or services at prices that do not reflect their user value, because of imperfect price discrimination due to asymmetric information and transaction costs, imperfect appropriability and imitation, or mismeasurement of the true value of the transaction due to the lack of hedonic prices." Knowledge spillovers occur when an $\mathrm{R} \& \mathrm{D}$ project produces knowledge that can be useful to another firm in doing its own research because of the inability to prevent knowledge from benefitting a competitor.).

109 See Graetz \& Doud, note 102, at 361-62 (summarizing the economic literature on the effect of increased R\&D on productivity and employment, and noting that the greatest effect of such spillovers are in nearby, rather than distant, locations).

110 See Eur. Comm'n, A Study on R\&D Tax Incentives: Final Report 17 (Nov. 28, 2014), https://ec.europa.eu/futurium/en/system/files/ged/28-taxud-study_on_rnd_tax_incen tives_-_2-14.pdf. Germany does not employ R\&D tax incentives, but provides substantial support to research and technology through public expenditures and public support for education. See Hemel \& Ouellette, note 23, at 307-09.

111 See text accompanying notes $158-61$. 


\section{B. From Theory to Practice}

\section{Should R\&D Be Subsidized? Which R\&D?}

There are studies that suggest that the social returns to $\mathrm{R} \& \mathrm{D}$ are greater, and in some studies much greater, than private returns. ${ }^{112}$ There is, however, little clarity about how to identify and test social benefits from specific R\&D. ${ }^{113}$

Assuming for the sake of discussion that the differences between social returns and private returns justify governmental support for private (for-profit) investment in $\mathrm{R} \& \mathrm{D}, 114$ it is necessary to identify which $R \& D$ should be the target for intervention. It is implausible that the gap between social and private returns is uniform for all R\&D. If there are differences, they should be taken into account, if possible, in designing $\mathrm{R} \& \mathrm{D}$ incentives.

The first step is to specify what we mean by $R \& D$ and then to differentiate among different kinds of $R \& D$ to assess the likelihood that the social return exceeds the private return. The scope of R\&D expenditures covered in $\S 174$, described above, ${ }^{115}$ may be compared with the definition used from the OECD's Frascati Manual, which is the internationally accepted standard practice for classifying expenditures in measuring research and experimental development:

Research and experimental development (R\&D) comprise creative work undertaken on a systematic basis in order to increase the stock of knowledge, including knowledge of man, culture and society, and the use of this stock of knowledge to devise new applications. ${ }^{116}$

112 See Joint Committee, note 70, at 7; Cong. Budget Office, R\&D and Productivity Growth: A Background Paper 23-28 (2005), https://www.cbo.gov/sites/default/files/cbo files/ftpdocs/64xx/doc6482/06-17-r-d.pdf; Int'l Monetary Fund, note 1, at 34 ("social rates of return to private $\mathrm{R} \& \mathrm{D}$ are generally estimated to be two to three times the private return" (emphasis omitted)); Zvi Griliches, R\&D, Education, and Productivity: A Retrospective 70 (2000) (surveying the literature to find that "[t]he estimated excess rate of return to $\mathrm{R} \& \mathrm{D}$ is about 25 percent on average"); Hall et al., note 18, at 1065-73 (surveying the economic literature and observing difficulties of measuring private and social returns to R\&D using case study and aggregate or macro methods).

113 See Hall \& Van Reenan, note 34, at 456-57.

114 See David et al., note 106, at 508; Hansson \& Brokelind, note 1, at 186. The general assumption is that $\mathrm{R} \& \mathrm{D}$ generates new knowledge and that new knowledge is the main source of new technological opportunities, which in turn are expected to result in higher private returns.

115 See Subsection II.B.1.

116 OECD, Frascati Manual 2002: Proposed Standard Practice for Surveys on Research and Experimental Development, The Measurement of Scientific and Technological Activities 30 (6th ed. 2002). 
The manual goes on to distinguish among basic research, applied research, and experimental development, ${ }^{117}$ as well as to describe the boundaries between $R \& D$ activity and non-R\&D activity in adjacent areas. 118

The essential difference between the $\S 174$ definition for qualifying $\mathrm{R} \& \mathrm{D}^{119}$ and that used by most countries appears to be the degree of novelty and risk that is necessary to qualify for an incentive. ${ }^{120}$ The lack of emphasis on novelty and experimental risk for the U.S. R\&D incentives as they are applied means that the incentive extends to activity that is less likely to involve a market failure of under-investment. Indeed, the more open-ended nature of the U.S. definition of R\&D expenditure has induced accounting firms to offer "R\&D studies" that amount to little more than inefficient expense characterization exercises for expenditures that already have been made. ${ }^{121}$

117 The three categories are described as follows:

Basic research is experimental or theoretical work undertaken primarily to acquire new knowledge of the underlying foundation of phenomena and observable facts, without any particular application or use in view. Applied research is also original investigation undertaken in order to acquire new knowledge. It is, however, directed primarily towards a specific practical aim or objective. Experimental development is systematic work, drawing on existing knowledge gained from research and/or practical experience, which is directed to producing new materials, products or devices, to installing new processes, systems and services, or to improving substantially those already Id. at 30 . produced or installed."

118 See id. at 30-33.

119 See notes 54-55 and accompanying text.

120 There are other definitional differences that are significant but not as central to our inquiry. One area for future work could be a systematic review of the differences between the definitions used for different purposes in the United States, in the OECD's Frascati Manual, and in other countries' R\&D tax incentives. See European Commission, note 110, at 59 (description of novelty requirements used by countries for R\&D incentives). As one example, the U.K. test for R\&D tax relief requires that the activity be directed at an advance in science or technology through the resolution of scientific or technological uncertainties. HM Revenue \& Customs, Corporation Tax: Research and Development tax relief (last updated 15 Apr. 2016), https://www.gov.uk/guidance/corporation-tax-research-anddevelopment-rd-relief. The economic literature describes these differences at a very high level and generally does not measure effects of differences in novelty required. See, e.g., Int'l Monetary Fund, note 1, at 30 ("The role of innovation in driving growth is difficult to analyze because of conceptual and data limitations. Most empirical work concentrates on the process of technological change, for which quantitative indicators are available, both as inputs (such as R\&D investment and the number of researchers) and outputs (such as the number of patents and publications."). R\&D investment is based on business enterprise $\mathrm{R} \& \mathrm{D}$, the standards for which may vary according to whether the data source is GAAP reporting or a Frascati-based methodology. See FASB Accounting Standards Codification Topic 730, Research and Development; OECD, Frascati Manual, note 116.

121 The PricewaterhouseCoopers (PwC) website advertises the Tax Products Delivery Group's R\&D credit services: "Stemming from our federal and state research tax credit law and examination experience, we have developed a flexible, customizable technology solution designed to build upon your existing technologies. Our unique web-based solu- 
Once the scope of what is meant as $R \& D$ is identified, the task then is to determine the $R \& D$ for which the social return exceeds the private return. It is customary to differentiate between basic $R \& D$ and development $\mathrm{R} \& \mathrm{D}$, though the exact line may be unclear. ${ }^{122}$ Basic $\mathrm{R} \& \mathrm{D}$ is generally thought to refer to work to acquire new knowledge of phenomena and observable facts without a particular or identified application or use as the objective. Development $R \& D$ is directed at drawing on existing knowledge to produce new materials, products, devices, processes, systems, or services. One would expect that basic $\mathrm{R} \& \mathrm{D}$ is riskier in terms of eventually generating a financial return.

Thus, it is not surprising that basic R\&D is much more heavily the province of public expenditure than private R\&D investment. ${ }^{123}$ Public expenditure on basic $R \& D$ is directed primarily to government and academic institutions, including the military, universities, and mostly nonprofit private research institutions. This may be because the subsidy that would be necessary to induce basic research by private firms would have to be substantial and would not be justified if the greater knowledge were monopolized by the private-sector participants. ${ }^{124}$ Moreover, as opposed to an open-ended tax credit for private parties, there are established procedures for government R\&D grants through the NSF and the NIH to utilize both government and university expertise and to include a peer review process to screen proposals for qual-

tion utilizes Microsoft SharePoint and is designed to minimize disruption to your business by incorporating data from existing payroll and ERP systems. Our team will review your current $\mathrm{R} \& \mathrm{D}$ tax credit methodology and existing technologies to identify opportunities to further leverage our team and technology." PricewaterhouseCoopers, Research and Development Credits Services, http://www.pwc.com/us/en/tax-products-delivery-group/research-development-credit.html (last visited Apr. 4, 2016). PwC is not unique among the Big Four accounting firms in providing these services.

A practitioner recently told one of the authors the following story about settling a claim for additional $R \& D$ credit on appeal:

Appeals: "[John,] do you have any idea what this R\&D does?"

[John]: "No, I have no .... . idea at all."

Appeals: "Neither do I. How about 50\%?"

While almost certainly apocryphal, the story conveys the flavor of what can happen when there is a weak definitional boundary and, as a result, it is difficult to assess accurately the hazards of litigation.

122 The OECD Frascati Manual differentiates among basic R\&D, applied R\&D, and experimental R\&D. See note 117. For purposes of this discussion, it is sufficient to differentiate between basic $R \& D$ and development $R \& D$.

123 See Int'l Monetary Fund, note 1, at 31; Ashish Arora, Sharon Belenzon \& Andrea Patacconi, Killing the Golden Goose? The Decline of Science in Corporate R\&D (Nat'l Bureau Econ. Research, Working Paper 20902, 2015), http://www.nber.org/papers/w20902.

124 The fact that the take-up of the university basic research credit is trivial in size supports this contention. See data cited in note 67 . 
ity. ${ }^{125}$ In light of the more speculative returns from basic $R \& D$, these protections seem quite sensible. ${ }^{126}$

While there may be a social return from both basic R\&D and development $\mathrm{R} \& \mathrm{D}$, the gap between social and private return likely is materially smaller for development R\&D. Presumably the pay-off period for successful basic R\&D is much longer than for development $\mathrm{R} \& \mathrm{D}$ and, when combined with the additional risk of failure and knowledge spillover, would require materially higher returns to justify private investment. One policy inference may be that it would be a mistake to cannibalize public expenditure on $\mathrm{R} \& \mathrm{D}$, and particularly basic $\mathrm{R} \& \mathrm{D}$, to incentivize private investment in development R\&D. Public and private R\&D investments may overlap in important ways, but they likely are more complements than substitutes for each other. ${ }^{127}$

Within the scope of development R\&D, the more experimental the research or development work is, the greater the risk of failure and the likelihood of under-investment. Establishing this differentiation is difficult in practice. As an indirect piece of evidence, a nonspecialist would tend to assume that a patented invention or matter likely would be the product of new knowledge having a relatively high social return, because of the requirement of nonobviousness to a person having ordinary skill in the subject for a patent to issue. ${ }^{128}$ Yet, based on somewhat dated data, almost half of litigated patent infringement cases are lost for lack of validity, and the most frequent statutory basis for the invalidity of the patent is that the patented invention is obvious. ${ }^{129}$ After changes in patent law review procedures, the Patent Trial and Review Board's invalidation percentage increased in 2015 to

125 The Hemel and Ouellette framework highlights that it is possible to include design features associated with a grant in a tax credit and vice versa. Hemel \& Ouellette, note 23, at 307. Nonetheless, much of the administrative efficiency of relying on taxation self-reporting is lost if the tax relief is conditioned on a government approval process. In the case of basic research, there would seem to be little advantage to reliance on a tax credit and there would be the disadvantages of not having the annual oversight and review of outlay expenditures.

126 Reliance on the government for decisionmaking, however, raises the specter of inefficient rent seeking by lobbyists. Moreover, there may be a difference in the level of takeup of subsidies awarded by grant. See European Commission, note 110, at 39-40 (describing economic literature on direct subsidies as ambiguous as to effectiveness).

127 The evidence on this point is ambiguous but points to complementarity. See David et al., note 106, at 525 .

12835 U.S.C. $\$ 103$ (a) (2000).

129 See Andrew Blair-Stanek, Profits as Commercial Success, 117 Yale L.J. 642, 646 (2008). This problem contributed to a provision modifying U.S. patent procedure to allow post-grant review of patents within nine months of the grant. Leahy-Smith America Invents Act, Pub. L. No. 112-29 § 6, 125 Stat. 286 (2012). This weakness in patent grants also calls into question the validity of using patents as a measure for evaluating innovation incentives. 
an astonishing $75 \%$ (compared to $31 \%$ in Europe). ${ }^{130}$ Even taking into account that these data pertain to challenged patents, this suggests that much of the R\&D that leads to patents may be development $\mathrm{R} \& \mathrm{D}$ with comparatively low social returns.

The difficulty of identifying socially useful development R\&D may be claimed as a reason why the government should leave it to the private market to identify $R \& D$ to be supported with a tax incentive. ${ }^{131}$ However, it is difficult to identify which $R \& D$ gives rise to knowledge or inventions that are not obvious (or at least satisfies the nonobviousness standard for patents). To this extent, an incentive may be misdirected at investments whose social benefits do not exceed the private return and encourage excessive investment in an activity as well as lose revenue that must be made up in other ways.

As noted above, the condition for deduction under $\S 174$ and for the R\&D tax credit is simply that the expenditure be for a new development. ${ }^{132}$ The uncertainty requirement has been watered down and there is no meaningful requirement that the activity be directed at resolution of scientific or technological uncertainties. Serious consideration should be given to revisiting the definition of $\mathrm{R} \& \mathrm{D}$ that qualifies for a tax benefit to increase the likelihood that the tax benefit applies to $R \& D$ whose social value exceeds the private benefit (that is, $R \& D$ that would not be carried on without the tax benefit).

\section{Supporting Innovation}

Work at the OECD and by students of innovation has shown that traditional concepts of knowledge leading to technological change and economic growth have been too narrow and must be broadened to include other elements of knowledge-based capital. ${ }^{133}$ This may raise a question whether R\&D tax incentives are aimed at the right target because the OECD's work emphasizes that growth based on innovation does not tie only to $\mathrm{R} \& \mathrm{D}$ in the traditional sense:

130 Douglas R. Nemic \& Scott M. Flanz, After Period of High Invalidation Rates, New US Patent Challenge Procedures May Slow Down to Moderate Pace (Apr. 26, 2016), https://www.skadden.com/insights/after-period-high-invalidation-rates-new-us-patent-challenge-procedures-may-slow-down-moder.

131 See Schizer, note 23, at 293-94. But see Rashkin, note 1, at 1063-64 (R\&D credit goes to the wrong companies for the wrong R\&D).

132 See notes 44, 54, and 59, and accompanying text. Research qualifies for the R\&D tax credit if it is undertaken for the purpose of discovering information that is technological in nature, is intended to be useful in the development of a new or improved business component of the taxpayer, and constitutes elements of a process of experimentation for a purpose that relates to a new or improved function, performance, or reliability or quality. IRC $\S 41(\mathrm{~d})$.

133 See OECD, note 8, at 3; Modica \& Neubig, note 8, at 7-11 (non-R\&D knowledgebased capital investment is important source of labor productivity and economic growth). 
While this programme of work has numerous intellectual antecedents, its immediate inspiration was a finding highlighted in the OECD's Innovation Strategy, published in 2010, that many innovating firms do not invest in R\&D. Instead, their innovation efforts are driven by investments in a broader range of intangibles assets, from software and large data sets to designs, firm-specific human capital and new organisational processes. These intangible assets are referred to . . . as knowledge-based capital. ${ }^{134}$

This understanding of innovation strategies, with its heavy emphasis on human creativity and its wide-ranging outputs, points to supporting the public investment in broadly-defined human capital and in the legal and physical infrastructure on which the private sector relies, instead of attempting to target a weakly specified market failure with expanded R\&D tax measures. Moreover, if social returns to $\mathrm{R} \& \mathrm{D}$ are correctly understood to be a residual, it highlights the dubious basis for attributing causality of those returns solely to narrowly-defined R\&D. Thus, the analysis of knowledge-based capital's role in innovation suggests that restrictive targeting of an incentive may not be justified. As described in the next Section, there also is evidence that small- and medium-size businesses, and newer businesses, respond more than large businesses to R\&D incentives. Accordingly, if one wants to use tax policy to encourage innovation, it may well be that lower tax rates targeted at newer businesses will be more effective than a narrower and poorly targeted R\&D incentive. ${ }^{135}$

\section{Whose R\&D Should Benefit?}

Determining who should receive $\mathrm{R} \& \mathrm{D}$ tax incentives is not an easy matter. For example, consider the import of availability of financing.

134 OECD, note 8, at 3; see also Modica \& Neubig, note 8, at 7-9 (non-R\&D knowledgebased capital intangible assets estimated to be $70 \%$ of total such capital stock and in some cases contribute more to productivity than $\mathrm{R} \& \mathrm{D}$ ). The finding that innovation may not be solely or even primarily linked to R\&D raises questions about the targeting of incentives.

135 See Hansson \& Brokelind, note 1, at 172 ("[E]conomists in general believe that providing tax incentives is a less effective means of attracting investment than lowering the general tax rate."); Martin A. Sullivan, Will International Tax Reform Slow U.S. Technology Development?, 141 Tax Notes 459, 463 (Nov. 4, 2013) ("Congress should not rule out eliminating or scaling back research incentives, especially when it has an attractive and undoubtedly beneficial alternative use of those funds: lowering the statutory corporate rate."); see also Joint Committee, note 70, at 19 ("The basic economic rationale [for a research tax credit] argues that a subsidy to reduce the cost of research should be equally applied across all sectors."); Rashkin, note 1, at 1061 (questioning whether companies respond to $R \& D$ incentives and arguing that "companies do $R \& D$ because they have to create products to compete regardless of whether there is a tax incentive"). 
A justification often given for $R \& D$ incentives is that under-investment in $R \& D$ results from an inability to obtain external financing. ${ }^{136}$ The level of risk, the lack of hard assets for collateral, the timing of positive cash flow returns, and the asymmetry of information between lender and borrower all make it difficult to obtain debt financing. $\mathrm{R} \& \mathrm{D}$ subsidies are said to mitigate this reason for under-investment in R\&D. ${ }^{137}$

Ironically, however, it is a common feature of business income tax incentives that most of the benefit goes to the largest and most profitable taxpayers who least need assistance. That is true for the R\&D tax credit as well. ${ }^{138}$ This may be justified on the ground that these taxpayers have demonstrated their efficiency and success, but it raises a question regarding the extent to which a scarcity of financing causes under-investment in private $\mathrm{R} \& \mathrm{D}$ among different categories of taxpayers. In particular, the financing problem will differ materially for creditworthy versus credit-constrained taxpayers and the latter will tend to be smaller and newer than the former.

Large taxpayers have multiple advantages in undertaking development R\&D that are not available to small- and medium-sized businesses and individual entrepreneurs. Large businesses can afford to diversify the risk through engaging in multiple projects and the knowledge from successful projects may be diffused more efficiently within a single enterprise. Large businesses have access to lower-cost financing in capital markets that would not be accessible by small- or medium-sized enterprises and entrepreneurs. ${ }^{139}$ In addition, a large business is more likely to have resources to devote to registering and protecting IP rights and bearing the other transactions costs that preserve and enhance returns to $\mathrm{R} \& \mathrm{D}$. If profitable, larger businesses can fully utilize input tax incentives, through either expensing R\&D or taking the R\&D credit. Large multinational businesses are able to use various tax planning strategies to take advantage of cross-border income shifting to increase their after-tax return. This planning will not end as a result of the OECD's Base Erosion and Profit Shifting (BEPS) project, ${ }^{140}$ because even if countries follow the OECD's BEPS recommendations in developing their own tax laws, BEPS only

136 See Hansson \& Brokelind, note 1, at 176; Int'l Monetary Fund, note 1, at 35.

137 See id.

138 In 2012, 84\% of corporate R\&D credit amounts were claimed by corporations with receipts over \$250 million. IRS, Statistics of Income 1990-2012: Totals of Research Credit Amounts, by Size of Business Receipts fig.C (2015), https://www.irs.gov/uac/SOI-Tax-StatsCorporation-Research-Credit; see also Kim, note 35, at 183 (80\% of R\&D credit distributed to corporations with over $\$ 250$ million of business receipts in 2001-2005).

139 See Hansson \& Brokelind, note 136, at 176.

140 See OECD, OECD/G20 Base Erosion and Profit Shifting Project 14 (2015), https:// www.oecd.org/ctp/beps-explanatory-statement-2015.pdf. 
targets some of the income-shifting strategies available to multinationals to increase their after-tax returns. The various BEPS proposals would not appear to affect the planning used by Microsoft to shift income into Puerto Rico. ${ }^{141}$

Small- and medium-sized businesses and entrepreneurs generally will not have the same resources, including access to financing, to achieve diversification and to expend on IP administration and protection. In many cases, they also will be enterprises with solely or primarily domestic operations that do not have the same cross-border tax savings opportunities. Some countries, however, have specifically directed $R \& D$ tax benefits to these smaller businesses and entrepreneurs or have provided more generous benefits to those types of taxpayers. ${ }^{142}$

A final incongruity is that the benefit of the R\&D credit goes disproportionately to the manufacturing sector (64\% in 2011) and far less to services. ${ }^{143}$ It is not clear why tax policy should favor this sector over others, particularly if the credit is not well-targeted to address a market inefficiency. If the credit were retained and more properly targeted, it might be possible to simplify the credit and make it available more easily.

In summary, the benefits of $\mathrm{R} \& \mathrm{D}$ tax incentives tend to be concentrated among taxpayers who least need assistance.

\section{Location of R\&D}

If tax incentives are going to be granted for private $\mathrm{R} \& \mathrm{D}$, should it matter where development $\mathrm{R} \& \mathrm{D}$ is performed? There is literature supporting the view that $\mathrm{R} \& \mathrm{D}$ spillovers are greatest in proximity to where $R \& D$ is performed. ${ }^{144}$ Evidence of the effect of tax incentives on the location of $R \& D$, however, is limited. ${ }^{145}$

In the analogous context of depreciation, accelerated depreciation is not allowed with respect to assets used outside the United States. ${ }^{146}$ As described above, the $R \& D$ tax credit is limited to $R \& D$ performed

\footnotetext{
141 See note 91 and accompanying text.

142 European Commission, note 110, at 20 (ten counties have R\&D incentives targeted at small businesses); Int'l Monetary Fund, note 1, at 35 (describing countries targeting small and new firms).

143 IRS, Statistics of Income 2011: Corporations Claiming a Credit for Increasing Research Activities tbl.1 (2015), https:/www.irs.gov/uac/SOI-Tax-Stats-Corporation-Research-Credit.

144 See, e.g., Graetz \& Doud, note 102, at 361.

145 See id. at 358-60; Maryann P. Feldman \& Dieter F. Kogler, Stylized Facts in the Geography of Innovation, in 1 Handbook of the Economics of Innovation, note 18, at 381. 146 IRC $\S 168(\mathrm{~g})(4)$.
} 
in the United States. ${ }^{147}$ It would seem a straightforward policy response, at a minimum, also to deny $\S 174$ expensing to foreign-performed $R \& D$ and require that $R \& D$ performed outside the United States be capitalized (if $\mathrm{R} \& \mathrm{D}$ is not capitalized generally, as discussed below). ${ }^{148}$

\section{Interaction of IP Protections with Tax Benefits}

Finally, there is an issue whether tax incentives should be allowed for $\mathrm{R} \& \mathrm{D}$ that later benefits from patent, trade secret, copyright, or similar market-enhancing legal protection. These nontax property rights allow the owner of the right to exclude use by another. While patent applications are public, other IP rights, such as trade secrets, allow an owner to prevent disclosure of the knowledge embedded in the IP and, in some states, may be a basis for employee and contractor noncompetition agreements. ${ }^{49}$ Joseph Stiglitz points out that IP rights have the effect of reducing the knowledge pool available to innovators, which may have a negative effect on $R \& D$ investment and the level of innovation. ${ }^{150}$ It is an important question whether the private benefits obtained from IP rights should serve as a basis for recouping a prior tax subsidy for $\mathrm{R} \& \mathrm{D}$ activity that led to those rights. ${ }^{151}$ If so, there could be a mechanism for recapture of R\&D tax expenditure benefits if the $R \& D$ is successful and results in ownership of IP rights. ${ }^{152}$ Alternatively, the grant of the tax incentive could be subject to an ex ante condition that the benefitted IP be subject to disclosure.

As the preceding discussion shows, an objective examination of the need for, and effectiveness of, $R \& D$ tax incentives in the context of the overall IP ecosystem is overdue.

\section{Are Tax R\&D Subsidies Effective?}

A leading, though now older, study by Bronwyn Hall and John Van Reenen of the effectiveness of R\&D tax incentives observes that ideally the analyst would measure the social return to $R \& D$ spending at

\footnotetext{
147 IRC $\S 41(\mathrm{~d})(4)(\mathrm{F})$.

148 Representative Camp's tax reform proposal would have provided for slower amortization for foreign R\&D. See H.R. 1, § 3108, 113th Cong., 2d Sess. (2014), https://www .congress.gov/bill/113th-congress/house-bill/1 (providing for five-year amortization of domestic $\S 174$ expenditures and fifteen-year amortization of foreign R\&D expenditures).

149 See, e.g., Cal. Penal Code $§ 499$ c (Deering 2016); Mass. Gen. Laws ch. 93, § 42 (LexisNexis 2016).

150 Stiglitz, note 11 , at 2-3.

151 See Joint Committee, note 70, at 7.

152 The reference to tax expenditure is meant to suggest that only the benefit that would not be allowed under a normal income tax would be subject to recapture.
} 
the margin in relation to the marginal benefit of alternative uses of tax dollars (for example, for deficit reduction, for human capital investment such as in education, or for lower tax rates). ${ }^{153}$ This has proven too difficult and, instead, most studies attempt to compare the incremental private $R \& D$ expenditure with the revenue cost of the incentive. ${ }^{154}$ This Hall and Van Reenen study suggests that given the present inability to disaggregate $\mathrm{R} \& \mathrm{D}$ into components that make strong contributions to economic growth and components that make lesser contributions to such growth, and into components that are highly responsive to incentives and those that are less so, it is not feasible to evaluate the social benefit of $R \& D$, its actual effect on economic growth (supposedly the underlying reason for favoring $\mathrm{R} \& \mathrm{D}$ investment), or the marginal effectiveness of the incentives. As summarized by Michael Graetz and Rachael Doud, "the economic literature suggests that $R \& D$ tax incentives may increase the amount of $\mathrm{R} \& \mathrm{D}$ and number of $\mathrm{R} \& \mathrm{D}$ employees but their cost effectiveness is less certain than their advocates claim." 155 This may be a generous reading of the efficacy of $R \& D$ tax incentives.

In the United States, dueling studies from the left and right political perspectives find some common ground in supporting R\&D tax incentives, ${ }^{156}$ but we actually have little reliable information on the welfare effects of current R\&D tax incentives. Consistent with our work on other tax expenditure issues, ${ }^{157}$ we would argue that the burden should be on the advocates of R\&D tax incentives to show that the recommended tax expenditure achieves its goals on a cost-effective basis such that the marginal social welfare benefit exceeds the opportunity cost of an alternative use of public revenue.

153 See Hall \& Van Reenen, note 34, at 456-57.

154 See Jason J. Fichtner \& Adam N. Michael, Mercatus Ctr. Geo. Mason U., Can a Research and Development Tax Credit Be Properly Designed for Economic Efficiency? 8 (2015); mercatus.org/sites/default/files/Fichtner-R-D-Tax-Credit.pdf; Laura Tyson \& Greg Lindon, Ctr. for Am. Progress, The Corporate R\&D Tax Credit and U.S. Innovation and Competitiveness: Gauging the Economic and Fiscal Effectiveness of the Credit 3 (2012), https://www.americanprogress.org/issues/tax-reform/report/2012/01/06/10975/the-corporate-rd-tax-credit-and-u-s-innovation-and-competitiveness/.

155 Graetz \& Doud, note 102, at 362. This is consistent with the findings of a European Commission staff working paper. See European Commission, note 110, at 39-40; see also Hansson \& Brokelind, note 1, at 189-91 (analysis of eighteen European countries shows no support for R\&D incentives having a significant positive impact on the number of patents, on inbound foreign direct investment, or on economic growth).

156 Compare Tyson \& Lindon, note 154, at 3 (recommending that the R\&D credit be made permanent and more generous), with Fichtner \& Michael, note 154, at 24-25 (favoring repeal of the credit and reducing the corporate tax rate or a second-best solution of making the credit permanent, eliminating claims on amended returns, expanding the definition of qualifying $R \& D$, and simplifying calculation of the credit).

157 See, e.g., Fleming \& Peroni, note 3, at 525-28. 


\section{Patent Boxes and Inter-Nation Tax Competition}

\section{Patent Boxes and BEPS Action 5}

A patent box or innovation box generally refers to a regime in which income attributed under some metric to a patent or similar property, or a related category of income, is taxed at a lower explicit rate or at a lower effective rate through allowance of a special deduction in relation to the income. ${ }^{158}$ Many European countries have adopted some form of patent box. ${ }^{159}$ The European Commission became concerned about patent boxes under European Union Code of Conduct rules and the OECD took up the issue as an example of potentially harmful tax competition. ${ }^{160}$ In both cases, countries have agreed that a condition for continued allowance of such regimes was that certain nexus requirements be satisfied. ${ }^{161}$

\section{Boustany-Neal Innovation Box Proposal}

In the United States, Representatives Charles Boustany and Richard Neal published a discussion draft of an innovation box proposal, the Innovation Promotion Act of 2015 (IPA 2015). ${ }^{162}$ IPA 2015 would allow a deduction equal to $71 \%$ of the lesser of innovation box profit or taxable income (determined without the IPA deduction) for the tax

158 See note 21; see also Annette Alstadsaeter, Salvador Barrios, Gaetan Nicodeme, Agnieszka Maria Skonieczna \& Antonio Vezzani, Patent Boxes Design, Patents Location and Local R\&D 8-9 (Euro. Comm'n, Taxation Papers No. 57, 2015), http://ec.europa.eu/ taxation_customs/resources/documents/taxation/gen_info/economic_analysis/tax_papers/ taxation_paper_57.pdf; see also Daniel Shaviro, The Crossroads Versus the Seesaw: Getting a "Fix" on Recent International Tax Policy Developments, 69 Tax L. Rev. 1, 34 (2015) ("The more plausible motivation for patent box rules is precisely that of engaging in tax competition with peer countries.").

159 Lewis J. Greenwald, Lucas Giardelli \& Christopher Odell, The Innovation Promotion Act of 2015: Not the New Ireland, 81 Tax Notes Int'l 439 (Feb. 1, 2016) (Belgium, Cyprus, Luxembourg: $80 \%$ deduction or exemption; United Kingdom: $10 \%$ tax rate; the Netherlands: $5 \%$ tax rate; Malta: full exemption; France: $15 \%$ tax rate; Hungary: $50 \%$ deduction from royalties from related parties; Spain: $60 \%$ exemption; Italy: $50 \%$ exemption).

160 See Alstadsaeter, et al., note 158, at 24-25 (patent boxes attract patents but do not increase local innovative activity; substance requirements may mitigate adverse revenue effects).

161 See OECD, Countering Harmful Tax Practices More Effectively, Taking into Account Transparency and Substance, Action 5-Final Report 24-37 (2015), http://www.keep eek.com/Digital-Asset-Management/oecd/taxation/countering-harmful-tax-practices-moreeffectively-taking-into-account-transparency-and-substance-action-5-2015-final-report_978 9264241190-en\#page1; Lillian V. Faulhaber, The Luxembourg Effect: Patent Boxes and the Limits of International Cooperation 17-25 (June 2016), papers.ssrn.com/sol3/ papers.cfm?abstract_id=2802281.

162 See H. Comm. on Ways and Means, 114th Cong., Innovation Promotion Act of 2015 Discussion Draft (2015), http://waysandmeans.house.gov/wp-content/uploads/2015/07/Innovation-Box-2015-Bill-Text.pdf [hereinafter IPA 2015]. 
year. ${ }^{163}$ Innovation box profits would start with "qualified gross receipts," which are those derived from "qualified property." "Qualified property" would be defined to mean any patent, invention, formula, process, design, pattern, or know-how, as well as any product made using those items; motion picture film or video; and computer software. ${ }^{164}$ The qualified gross receipts would be reduced by properly allocable expenses. ${ }^{165}$ To determine the qualifying profit, the tentative profit would be multiplied by the ratio of five-year R\&D expenditures performed in the United States to five-year total costs of the taxpayer (exclusive of cost of goods sold, interest, and taxes). ${ }^{166}$

The proposal would in effect be consistent with the BEPS Action $5^{167}$ nexus requirements because the benefit effectively would be measured by R\&D performed by the taxpayer in the United States. In an effort to attract R\&D back to the United States, IPA 2015 would allow a tax-free distribution by a CFC of intangible property if certain conditions are satisfied. ${ }^{168}$

The proposal has been criticized, in part on the ground that the ratio used penalizes businesses that have high below-the-line expenses, such as selling, and general and administrative expenses, including marketing expenses. ${ }^{169}$ In addition, the rate reduction is characterized as "hardly newsworthy." 170

Our criticisms come from a different perspective. As observed by others, the proposal would be less effective at inducing new $R \& D$ than an input incentive, and would be a windfall for pre-existing R\&D. ${ }^{171}$ The proposal's design would not actually target returns to $R \& D$, except on a formulary basis, and would not provide benefits to failed $R \& D$ or $R \& D$ that is not commercialized, which, as discussed above, may also create positive spillovers. ${ }^{172}$ For these reasons, we conclude that the proposed innovation box is a poorly targeted rate reduction that should not be enacted into law.

\footnotetext{
163 Id. at $\S 2$ (a) (proposing $\S 250$ Innovation Box Profits).

164 Id.

165 Id.

166 Id.

167 OECD, note 162.

168 See IPA 2015, note 162 , at $\S 3(\mathrm{a})$.

169 See Greenwald et al., note 159, at 442.

170 Id.

171 See Martin A. Sullivan, Economic Analysis: Patent Boxes, Research Credits, or Lower Rates?, 147 Tax Notes 975, 975 (June 1, 2015) (innovation box provides windfall benefit to prior successful research that provides no incentive for new effort); White House, note 6, at 22; Int'l Monetary Fund, note 1, at 52-53 (IP box can discriminate against innovations not protected by IP, may induce applications for IP rights, and provide relief without regard to level of $R \& D$ expenditure).

172 See Martin A. Sullivan, A History Lesson for a Future Patent Box, 148 Tax Notes 1036, 1037-38 (Sept. 7, 2015); European Commission, note 110, at 45-46.
} 


\section{A Framework for R\&D Tax Expenditure Analysis}

\section{A. Elements of a Framework for R\&D Tax Incentives}

In our view, tax expenditures with the greatest potential for revenue savings through their elimination and the least connection to their asserted objectives should be given a higher priority for review. In examining tax expenditures, it is important to apply the same analytical scrutiny and principles to "sacred cow" tax expenditures, including the R\&D tax expenditures, as well as to more controversial ones.

Consistent with our prior work examining other tax expenditures, several elements should be a part of a nuanced framework for examining $\mathrm{R} \& \mathrm{D}$ tax incentives, including the following:

- Is the provision a tax expenditure?173

- Does the subsidy address a market failure and does it target effectively the market failure? ${ }^{174}$

- Is the provision cost effective in achieving its target?

- Are there direct expenditure or regulatory alternatives to tax incentives that would be more effective in achieving the target?

- Would design changes improve the cost effectiveness of the tax incentive?

Our reading of the $\mathrm{R} \& \mathrm{D}$ literature is that there is uncertain empirical support for a conclusion that $\mathrm{R} \& \mathrm{D}$ incentives for private sector development $R \& D$ are cost effective in the sense of increasing social welfare and economic growth when compared with alternative public uses of funds. If this reading is correct, and even if it is not, but it becomes fiscally necessary to reduce $R \& D$ tax incentives, our proposed framework for analysis readily points to a number of proposals for further investigation and analysis.

\section{B. Proposals for Further Analysis}

Our tentative conclusion is that R\&D tax incentives are not well targeted, in large part because we lack a clear understanding of the extent to which private R\&D would not be conducted absent government intervention produces welfare benefits. We do not know and are not likely to be able to estimate with accuracy the size of the differential between the private and social benefits from private R\&D invest-

173 David Hasen has suggested to us that use of the tax expenditure concept here may be considered a proxy for a market distorting provision.

174 See Willem Bongaerts \& Ivo IJzerman, The Secrets to Success of the Dutch Innovation Box, 82 Tax Notes Int'l 479 (2016) (summarizing a Dutch government report finding that 1 Euro of revenue lost by the Dutch patent box yields 0.54 Euros of R\&D expenditure). 
ment and whether the social benefits from intervention would exceed the welfare costs. In this circumstance, we do not believe that the case for R\&D tax expenditures has been adequately proven.

Accordingly, we believe that an objective analysis of alternatives is overdue. We are particularly skeptical of open-ended tax benefits for private $R \& D$. We believe that resources should be directed to basic $\mathrm{R} \& \mathrm{D}$, which may be more effectively directed through and performed by government, university, and other nonprofit research entities, and that outcomes should be made public and not appropriated for private gain. We favor an instrument, such as a government grant process using external blind peer reviews of proposals, to allocate resources rather than a tax incentive. Accordingly, we would first pursue analysis of the effects of the Group 1 proposals below.

If it is politically necessary to continue to use tax incentives to encourage innovation or there is strong empirical support for using such incentives, we would rely on input incentives only. Moreover, we would favor adoption of the Group 2 proposals below to constrain costs and better target incentives to R\&D likely to enhance U.S. welfare.

\section{Group 1 - Alternatives to R\&D Tax Incentives}

- Repeal R\&D tax incentives

- Shift revenue savings to direct expenditures for peer-reviewed $R \& D$ proposals oriented toward basic $R \& D$ and risky development R\&D

\section{Group 2 - Capitalization}

- Capitalize (that is, deny the $\S 174$ deduction for) all R\&D (as in the Baucus and Camp tax reform proposals, ${ }^{175}$ including foreign R\&D)

- Eliminate the $\S 59(\mathrm{e})$ ten-year capitalization rule

- Use credits instead of deductions for incentive purposes and consider credit refundability for new (that is, less than 5 years old) small- and medium-sized businesses

- Restrict scope of R\&D tax incentives (that is, tax expenditures) to NSF or Frascati definitions of experimental R\&D.

175 H.R. 1, note 148, $\S 3108$ (providing for five-year amortization of domestic $\S 174$ expenditures and fifteen-year amortization of foreign R\&D expenditures); S. Fin. Comm., Majority Staff, Chairman's Staff Discussion Draft, § 22 (2013), http://www.finance.senate .gov/imo/media/doc/Chairman's\%20Staff\%20Discussion \%20Draft \%20on \%20Cost \%20Re covery\%20and\%20Accounting \%20Language.pdf (providing for five-year amortization of $\S 174$ expenditures). 
- Restrict R\&D tax incentives to domestic-performed R\&D.

\section{Conclusions}

The United States should develop its tax and nontax R\&D and innovation strategies on an integrated basis. Tax law incentives should be re-examined without preconceptions (along with reforms to IP law) to reduce costs and inefficiencies. Moreover, support should be given to developing metrics for evaluating the comparative impact of R\&D tax incentives and direct $\mathrm{R} \& \mathrm{D}$ expenditures. Irrespective of one's views regarding the size and role of government, government interventions through tax incentives and regulatory action should receive the same scrutiny as direct government expenditures.

Our analysis suggests that applying a simple and straightforward framework that employs traditional tax policy analysis leads to a conclusion that reforms to existing $\mathrm{R} \& \mathrm{D}$ tax incentives would increase their efficiency and effectiveness. The proposals described in the preceding Part merit serious analysis and consideration. 
APPEndix

Selected Tax Expenditure Estimates ${ }^{176}$

Treasury Tax Expenditures

FY 2016-2025

(\$ millions)

Expensing of research and experimentation expenditures

73,410

Credit for increasing research activities

20,630

Deferral of tax on income from CFCs

852,580

\section{Joint Committee Tax Expenditures}

FY 2015-2019

(\$ billions)

Therapeutic research credit

0.8

Credit for orphan drug research

5.3

credit for research and experimentation expenses*

Deferral of tax on active income of controlled foreign corporations

Apportionment of research and development expenses for determination of foreign tax credits

* At the time of the report, the R\&D credit was set to expire and had not yet been made permanent.

\section{Joint Committee Revenue Estimate}

FY 2016-2025

(\$ millions)

Research credit permanently extended and modified 
TAX LAW REVIEW 